\title{
Identification of cost-optimal and NZEB refurbishment levels for representative climates and building typologies across Europe
}

\author{
Paolo Zangheri (D) Roberto Armani • Marco Pietrobon • \\ Lorenzo Pagliano
}

Received: 30 November 2016/Accepted: 4 September 2017 /Published online: 19 September 2017

(C) The Author(s) 2017. This article is an open access publication

\begin{abstract}
The energy consumptions of the building stock are playing a central role in the energy policy of the European Union. While the Member States are applying the Directives in force, the European Commission is working to update the regulatory framework. Specifically, it is necessary to achieve the great unrealized potential for energy savings in existing buildings. With this aim, the nearly zero-energy building (NZEB) target was introduced, and a comparative methodology framework to calculate cost-optimal levels of minimum energy performance requirements was proposed. This study focuses on the issue of building renovation, and it presents the results obtained with the application of a cost-optimal calculation method for identifying proper retrofit measures to reach costoptimal levels and NZEB levels. The assessment takes into account an exhaustive set of passive and active renovation options and it was extended to various building types of $60 \mathrm{~s}-70 \mathrm{~s}$ (residential and non-residential) in a wide range of representative European climatic conditions. A very relevant energy-saving potential was found for all cost-optimal benchmarks, and in many
\end{abstract}

\author{
P. Zangheri $(\bowtie)$ \\ Directorate C - Energy, Transport and Climate, Joint Research \\ Centre (JRC), Ispra, VA, Italy \\ e-mail: paolo.zangheri@ec.europa.eu \\ P. Zangheri \\ DTE-SEN, ENEA, Ispra, VA, Italy
}

R. Armani · M. Pietrobon · L. Pagliano end-use Efficiency Research Group, Dipartimento di Energia (eERG), Politecnico di Milano, Milan, Italy cases, the obtained NZEB refurbishments have resulted interesting also from an economic point of view.

Keywords EPBD recast $\cdot$ NZEB $\cdot$ Cost-optimal calculation $\cdot$ Retrofit measures

\section{Introduction}

Motivation

The European building stock consumes approximately $40 \%$ of primary energy, and it is responsible for $36 \%$ of the EU greenhouse gas emissions. A significant reduction of this energy demand is a requisite to meet Europe's GHG emission reduction targets, and buildings are a strategic sector for the European energy policy. In fact, it is a pillar of the Energy Union as set by the 2015 Communication $^{1}$ of the European Commission (EC). The Energy Performance of Buildings Directive (EPBD)-together with the Energy Efficiency Directive (EED) and the Renewable Energy Directive (RED) - defined a framework that creates the conditions for long-term improvements in the energy performance of Europe's building stock. Without it, the indicative target at the EU level of at least $27 \%$ for improving energy efficiency in $2030^{2}$ cannot be obtained.

In the frame of the implementation of the European Directive 2010/31/EU (EPBD recast by the European

\footnotetext{
$\overline{{ }^{1} \mathrm{COM} / 2015 / 080}$ final.

2 This will be reviewed by 2020 , having in mind an EU level of $30 \%$.
} 
Parliament 2010), the EU Member States were asked to develop policies appropriate to their national situations and provide the necessary financing to foster the transition to nearly zero-energy building (NZEB). The EPBD recast requires that from 2019 onwards, all new buildings occupied and owned by public authorities are NZEBs and all new buildings by the end of 2020 . However, acknowledging the variety in building culture and climate throughout Europe, the EPBD does not prescribe a uniform approach for implementing NZEB. Member States were required to draw up National Plans for increasing the number of NZEBs, with targets that may be differentiated for different building categories. According to paragraph 3 of Article 9, these plans shall include NZEB definitions reflecting national, regional, or local conditions, and a numerical indicator of primary energy use.

Moreover, the EPBD recast asked Member States to calculate cost-optimal levels of minimum energy performance requirements for new and existing buildings by using the comparative methodology framework established by the Commission with the Delegated Act No. 244/2012 (European Parliament 2012a, b) of 16 January 2012 (including explanatory guidelines).

This cost-optimal calculation framework involves the following steps: (i) definition of national reference buildings representing national building stock, (ii) identification of energy efficiency measures and packages to be evaluated, (iii) calculation of primary energy demand of the reference buildings with the identified energy efficiency measures, (iv) calculation of global costs related to each the energy efficiency measure and package considering long-term expenditures and savings during the calculations period, (v) sensitivity analysis for input data, and (vi) derivation of cost-optimal levels of energy performance requirements.

While the Member States are updating their plans, the cost-optimal approach may be very effective both to upgrade the energy performance requirements in force at the national level ${ }^{3}$ and to assess the effects of policy measures implemented or proposed by the Member States to achieve the NZEB target, particularly in the case of policy measures based on financial incentives for

\footnotetext{
${ }^{3}$ It is provided that if the result of the comparative analysis carried out shows that the minimum requirements in force are considerably less efficient than those arising from the analysis of the cost-optimal levels (deviation greater than $15 \%$ ), the MS must give justification for this difference or develop a plan outlining the appropriate measures to be introduced in order to reduce significantly the energy gap.
}

energy efficiency (EE) and renewable energy systems (RES) technologies and the transformation of these technologies national markets.

\section{Literature review}

In general application of optimization, methods for lowenergy and sustainable building design (including also the cost-optimal objective) are well summarized in the review analyses by Evins (2013), Nguyen et al. (2014) and Machairas et al. (2014). Further review studies on these subjects more specifically focusing on NZEB developments are presented by Attia et al. (2013) and Lu et al. (2015). Several examples of application of this method also with the aim of determine the optimum in terms of energy performances and costs (life cycle or initial costs) are presented in numerous studies (Diakaki et al. 2008; Brown et al. 2010; Morrissey and Horne 2011; Asadi et al. 2012; Fesanghary et al. 2012; Kumbaroğlu and Madlener 2012; Rysanek and Choudhary 2013; Nguyen and Reiter 2014; Penna et al. 2015).

In literature, while it is available also, an extensive literature on the cost optimization of specific building element calculation - e.g., the optimal insulation thickness for the various building elements and in various climatic conditions, as summarized by Fokaides and Papadopoulos (2014) — rarer is the published applications of cost optimization procedures on the whole buildingplant system and only some of these refer explicitly to the framework of EPBD Recast Directive. Because the method described in this paper is proposed as a direct application of the European comparative approach, the following previous experiences were considered particularly relevant: Kurnitski et al. (2011), Hamdy et al. (2013, Corrado et al. (2014), Ganic and Zerrin Y1lmaz (2014), Pikas et al. (2014), Ferrara et al. (2014), Brandão de Vasconcelos et al. (2016), Becchio et al. (2016), Ashrafiana et al. (2016), Ortiz et al. (2016a, b).

From a methodological point of view, the majority of previous studies have focused on a limited number of building variants, selected through a combination of technical measures/packages or applying (more or less sophisticated) multi-stage search-optimization techniques (Table 1). Often to quantify the energy needs for heating, cooling, and lighting, the calculations were made by dynamic simulations, while the computation of final energy uses could be obtained by more simplified calculations (e.g., semi-stationary methods). For 
Table 1 Literature review: general methodology

\begin{tabular}{|c|c|c|c|c|}
\hline Reference & $\begin{array}{l}\text { Calculation of } \\
\text { energy needs }\end{array}$ & $\begin{array}{l}\text { Calculation of final } \\
\text { energy demand }\end{array}$ & $\begin{array}{l}\text { Solving } \\
\text { method }\end{array}$ & $\begin{array}{l}\text { Number } \\
\text { of building } \\
\text { variants }\end{array}$ \\
\hline Kurnitski et al. 2011 & $\begin{array}{l}\text { Dynamic simulation } \\
\text { with IDA-ICE }\end{array}$ & $\begin{array}{l}\text { Dynamic simulation } \\
\text { with IDA-ICE }\end{array}$ & $\begin{array}{l}\text { Combination of the considered } \\
\text { measures/packages }\end{array}$ & $<50$ \\
\hline Hamdy et al. 2013 & $\begin{array}{l}\text { Dynamic simulation } \\
\text { with IDA-ICE }\end{array}$ & $\begin{array}{l}\text { Simplified methods } \\
\text { and auxiliary } \\
\text { design calculations }\end{array}$ & $\begin{array}{l}\text { Automatic multi-stage } \\
\text { optimization } \\
\text { method based on multi- } \\
\text { objective } \\
\text { genetic algorithm }\end{array}$ & 3400 \\
\hline Corrado et al. 2014 & $\begin{array}{l}\text { Semi-stationary } \\
\text { method } \\
\text { (EN 13790) }\end{array}$ & $\begin{array}{l}\text { Semi-stationary } \\
\text { method } \\
\text { (EN 13790) }\end{array}$ & $\begin{array}{l}\text { Sequential search-optimization } \\
\text { technique }\end{array}$ & $<50$ \\
\hline Ganic and Zerrin Y1lmaz 2014 & $\begin{array}{l}\text { Dynamic simulation } \\
\text { with EnergyPlus }\end{array}$ & $\begin{array}{l}\text { Dynamic simulation } \\
\text { with EnergyPlus }\end{array}$ & $\begin{array}{l}\text { Combination of the considered } \\
\text { measures/packages }\end{array}$ & $<50$ \\
\hline Pikas et al. 2014 & $\begin{array}{l}\text { Dynamic simulation } \\
\text { with IDA-ICE } \\
\text { (1 floor) }\end{array}$ & $\begin{array}{l}\text { Dynamic simulation } \\
\text { with IDA-ICE } \\
\text { (fixed HVAC) }\end{array}$ & $\begin{array}{l}\text { Iterative three-step wise } \\
\text { optimization }\end{array}$ & $<50$ \\
\hline Ferrara et al. 2014 & $\begin{array}{l}\text { Dynamic simulation } \\
\text { with TRNSYS }\end{array}$ & $\begin{array}{l}\text { Dynamic simulation } \\
\text { with TRNSYS }\end{array}$ & $\begin{array}{l}\text { Simulation-based optimization } \\
\text { process }(\mathrm{GenOpt})\end{array}$ & 6000 \\
\hline $\begin{array}{l}\text { Brandão de Vasconcelos et al. } \\
\quad 2016\end{array}$ & $\begin{array}{l}\text { Dynamic simulation } \\
\text { with EnergyPlus }\end{array}$ & $\begin{array}{l}\text { Dynamic simulation } \\
\text { with EnergyPlus } \\
\text { (fixed HVAC) }\end{array}$ & $\begin{array}{l}\text { Combination of the considered } \\
\text { measures (for envelope only) }\end{array}$ & 35,000 \\
\hline Becchio et al. 2016 & $\begin{array}{l}\text { Dynamic simulation } \\
\text { with EnergyPlus }\end{array}$ & $\begin{array}{l}\text { Dynamic simulation } \\
\text { with EnergyPlus }\end{array}$ & $\begin{array}{l}\text { Combination of the considered } \\
\text { measures }\end{array}$ & $<50$ \\
\hline Ashrafiana et al. 2016 & $\begin{array}{l}\text { Dynamic simulation } \\
\text { with EnergyPlus }\end{array}$ & $\begin{array}{l}\text { Dynamic simulation } \\
\text { with EnergyPlus }\end{array}$ & $\begin{array}{l}\text { Combination of the considered } \\
\text { measures (for envelope only) }\end{array}$ & 55 \\
\hline Ortiz et al. 2016a, b & $\begin{array}{l}\text { Dynamic simulation } \\
\text { with TRNSYS }\end{array}$ & $\begin{array}{l}\text { Simplified methods } \\
\text { and auxiliary design } \\
\text { calculations }\end{array}$ & $\begin{array}{l}\text { Combination of the considered } \\
\text { measures }\end{array}$ & 2000 \\
\hline
\end{tabular}

example, this is the case of Hamdy's (2013) analysis, which developed a multi-stage methodology based on a multi-objective genetic algorithm able to reduce the number of the building envelope simulations and, in a second time, applying appropriate efficiency factors to optimize the plant systems. In this way, he has increased the number of considered building variants compared to other studies. With this aim also, Ferrara et al. (2014) applied a simulation-based optimization process, combining the use of TRNSYS (Solar Energy Laboratory 2012) with GenOpt (Wetter 2008). Brandão de Vasconcelos et al. (2016), who considers only the envelope technologies, adopted a two-step approach which consists in (i) preliminarily discarding of measures with the same or worse thermal transmission coefficient and higher global costs comparatively with other measures and (ii) combination of all resulting measures with each other, creating 35,000 packages of measures. A good number of building variants (i.e., 2000) was considered also by Ortiz (Ortiz et al. 2016a, b), who conversely applied a "brute-force" approach to obtain a complete characterization of the problem.

As shown in Table 2, the most considered energy end-uses are space heating, cooling, and lighting. In line with the EPBD, the appliances (e.g., domestic equipment) are rarely taken into account. The energy calculations were made referring to similar indoor comfort conditions by the authors.

About the cost calculation (Table 3), all authors referred to a financial perspective (including taxes and not monetizing the environmental damage of emissions) and - except Kurnitski et al. (2011), who did not taken into account maintenance, replacement, and disposal costs - they considered all cost items indicated by the Commission Delegated Act No. 244/2012 (European Parliament 2012a, b). A real interest rate between 2 and $4 \%$ and a yearly increase of energy prices around $2 \%$ were used.

On the application side (Table 4), the majority of previous studies have focused on residential building 
Table 2 Literature review: energy calculation

\begin{tabular}{|c|c|c|c|c|}
\hline Reference & Energy uses considered & $\begin{array}{l}\text { Electric primary } \\
\text { energy factor }\end{array}$ & $\begin{array}{l}\text { PV energy taken } \\
\text { into account }\end{array}$ & $\begin{array}{l}\text { Temperature set-points } \\
\text { in winter and summer }\end{array}$ \\
\hline Kurnitski et al. 2011 & $\begin{array}{l}\text { Heating, cooling, ventilation, } \\
\text { pumps and fans, other } \\
\text { technical service systems, } \\
\text { DHW, lighting }\end{array}$ & 1.5 & n.a & n.a-n.a \\
\hline Hamdy et al. 2013 & $\begin{array}{l}\text { Heating, cooling, ventilation, } \\
\text { pumps and fans, other t } \\
\text { echnical service systems, } \\
\text { DHW, lighting, appliances }\end{array}$ & 1.7 (for Finland) & $\begin{array}{l}\text { Self-consumed } \\
\text { (by hourly load } \\
\text { matching operation) }\end{array}$ & n. $\mathrm{a}-25^{\circ} \mathrm{C}$ \\
\hline Corrado et al. 2014 & Heating, cooling and DHW & 2.17 (for Italy) & $\begin{array}{l}\text { Self-consumed } \\
\text { (by monthly load } \\
\text { matching operation) }\end{array}$ & $20^{\circ} \mathrm{C}-26^{\circ} \mathrm{C}$ \\
\hline Ganic and Zerrin Y1lmaz 2014 & Heating, cooling and lighting & 2.35 (for Turkey) & Not considered & $21^{\circ} \mathrm{C}-26^{\circ} \mathrm{C}$ \\
\hline Pikas et al. 2014 & Heating, cooling and lighting & n.a & $\begin{array}{l}\text { Self-consumed } \\
\text { (by hourly load } \\
\text { matching operation) } \\
\text { and exported } \\
\text { to the grid }\end{array}$ & n.a-n.a \\
\hline Ferrara et al. 2014 & Heating, cooling & 2.58 & n.a & n.a-n.a \\
\hline Brandão de Vasconcelos et al. 2016 & $\begin{array}{l}\text { Heating, cooling, ventilation, } \\
\text { pumps and fans, other } \\
\text { technical service systems, } \\
\text { DHW }\end{array}$ & n.a & Not considered & n.a-n.a \\
\hline Becchio et al. 2016 & $\begin{array}{l}\text { Heating, cooling, DHW, } \\
\text { lighting and appliances }\end{array}$ & 2.18 (for Italy) & n.a & $21^{\circ} \mathrm{C}-26^{\circ} \mathrm{C}$ \\
\hline Ashrafiana et al. 2016 & $\begin{array}{l}\text { Heating, cooling, DHW, } \\
\text { lighting }\end{array}$ & 2.36 (for Turkey) & Not considered & $20^{\circ} \mathrm{C}-26^{\circ} \mathrm{C}$ \\
\hline Ortiz et al. 2016a, b & $\begin{array}{l}\text { Heating, cooling, DHW, } \\
\text { lighting and appliances }\end{array}$ & 2.464 (for Spain) & n.a & $20^{\circ} \mathrm{C}-24.5^{\circ} \mathrm{C}$ \\
\hline
\end{tabular}

n.a not available

types, covering both the ambit of new design and building retrofit. Analyses on cost-optimal levels are mainly based on identification of energy efficiency measures/packages affecting energy performance of buildings, but, in general, the most investigated systems were the envelope solutions and the heating generators. In any study, the same calculation methodology was applied to more than two building types and more than three weather conditions.

Even though it is not trivial to compare the results obtained under different simplified assumptions and calculation methods, these previous experiences found cost-optimal primary energy levels in the range $90-150 \mathrm{kWh} / \mathrm{m}^{2} /$ year. The authors, who did this type of comparison, found that the primary energy targets related to the costoptimal levels are significant lower (20-50\%) than those related to the standard requirements, in force at national level.
This same conclusion was derived from the analysis of the first cost-optimal calculations done by the Member States. Boermans et al. (2015) observes that about half of the EU countries reveal a significant gap (i.e., larger than $15 \%$ ) between the cost-optimal levels and the energy requirements in force. The picture is very similar for the different building types and for both new and renovated buildings. From the methodological point of view, it is interesting to observe that about half of the national methodologies are in line with the CEN standards and refer to them (at least partly) for the calculation of primary energy and global cost. However, in most cases, the primary energy calculation is considered non fully reliable because the primary energy is not always used as energy performance indicator, the value of primary energy factors is low, and not all technical systems are addressed (Zirngibl and Bendzalova 2015). 
Table 3 Literature review: global cost calculation

\begin{tabular}{|c|c|c|c|c|c|}
\hline Reference & Considered costs & $\begin{array}{l}\text { Economic } \\
\text { perspective }\end{array}$ & $\begin{array}{l}\text { Building's } \\
\text { lifetime (year) }\end{array}$ & $\begin{array}{l}\text { Real interest } \\
\text { rate }(\%)\end{array}$ & $\begin{array}{l}\text { Annual increase } \\
\text { of energy prices }\end{array}$ \\
\hline Kurnitski et al. 2011 & $\begin{array}{c}\text { Energy, labor, materials, } \\
\text { overheads and taxes }\end{array}$ & Financial & 30 & 3 & $2 \%$ \\
\hline Hamdy et al. 2013 & $\begin{array}{l}\text { Energy, labor, materials, } \\
\text { maintenance, replacement, } \\
\text { disposal and taxes }\end{array}$ & Financial & 30 & 3 & $2 \%$ \\
\hline Corrado et al. 2014 & $\begin{array}{l}\text { Energy, labor, materials, } \\
\text { maintenance, replacement, } \\
\text { disposal and taxes }\end{array}$ & Financial & 30 & 4 & $\begin{array}{l}\text { Electric } 2 \% \\
\text { Gas } 2.8 \%\end{array}$ \\
\hline Ganic and Zerrin Y1lmaz 2014 & $\begin{array}{l}\text { Energy, labor, materials, } \\
\text { maintenance, replacement, } \\
\text { disposal and taxes }\end{array}$ & Financial & 20 & 4.12 & n.a \\
\hline Pikas et al. 2014 & $\begin{array}{l}\text { Energy, labor, materials, } \\
\text { maintenance, replacement, } \\
\text { disposal and taxes }\end{array}$ & Financial & 20 & 4 & n.a \\
\hline Ferrara et al. 2014 & $\begin{array}{l}\text { Energy, labor, materials, } \\
\text { maintenance, replacement, } \\
\text { disposal and taxes }\end{array}$ & Financial & 30 & 4 & $2 \%$ \\
\hline Brandão de Vasconcelos et al. 2016 & $\begin{array}{l}\text { Energy, labor, materials, } \\
\text { maintenance, replacement, } \\
\text { disposal and taxes }\end{array}$ & Financial & 30 & 3 & $\mathrm{n} \cdot \mathrm{a}^{\mathrm{a}}$ \\
\hline Becchio et al. 2016 & $\begin{array}{l}\text { Energy, labor, materials, } \\
\text { maintenance, replacement, } \\
\text { disposal and taxes }\end{array}$ & Financial & 30 & 2.3 & n.a \\
\hline Ashrafiana et al. 2016 & $\begin{array}{l}\text { Energy, labor, materials, } \\
\text { maintenance, replacement, } \\
\text { disposal and taxes }\end{array}$ & Financial & 30 & $2.4^{\mathrm{b}}$ & n.a \\
\hline Ortiz et al. $2016 \mathrm{a}, \mathrm{b}$ & $\begin{array}{l}\text { Energy, labor, materials, } \\
\text { maintenance, replacement, } \\
\text { disposal and taxes }\end{array}$ & Financial & 30 & $2.5^{\mathrm{c}}$ & $\begin{array}{l}\text { Electric } 2.5 \% \\
\text { Gas } 2 \%\end{array}$ \\
\hline
\end{tabular}

n.a not available

${ }^{a}$ The authors refer to the EU's forecasts for energy costs trends (European Commission 2014)

${ }^{\mathrm{b}}$ Calculated as difference between the market interest rate $(11.25 \%)$ and the inflation rate $(8.85 \%)$

${ }^{\mathrm{c}}$ Calculated as difference between the market interest rate $(4.5 \%)$ and the inflation rate $(2 \%)$

Generalizing the issue, it is interesting to remember that some critical points on the cost-optimal method itself were discussed. For instance, Tadeu et al. (2016) consider that the global cost indicator is not enough for describing the point of view of an investor and it must be complemented with additional information. Becchio et al. (2015) stressed the need to include in the global cost formula other benefits related to energy-design of buildings (as indoor comfort conditions, reduction of $\mathrm{CO}_{2}$ emissions, embodied energy, real estate market value).

\section{Objectives and overview}

Against the regulatory background, the main objective of this study is to identify primary energy levels and benchmarks for building renovation which may represent the cost-optimal and NZEB ${ }^{4}$ targets across Europe.

The paper covers the main aspects discussed above and it proposes an additional calculation method consistent with the European framework (European Parliament 2012a, b). Compared to previous methods and applications, (i) it is single stage rather than multi-

\footnotetext{
${ }^{4}$ Referring to the analysis of Marszal et al. 2011, this study is based on the "ZEB limited" definition: a low-energy building, fulfilling any national/local energy efficiency requirements, which offsets the yearly balance between its weighted energy demand for heating, DHW, cooling, ventilation, auxiliaries and built-in lighting, and the weighted energy supplied by on-site generation systems driven by on- or off-site sources and connected to the energy infrastructure. Static (or quasistatic) and symmetric primary energy factors are used as weights in the balance.
} 


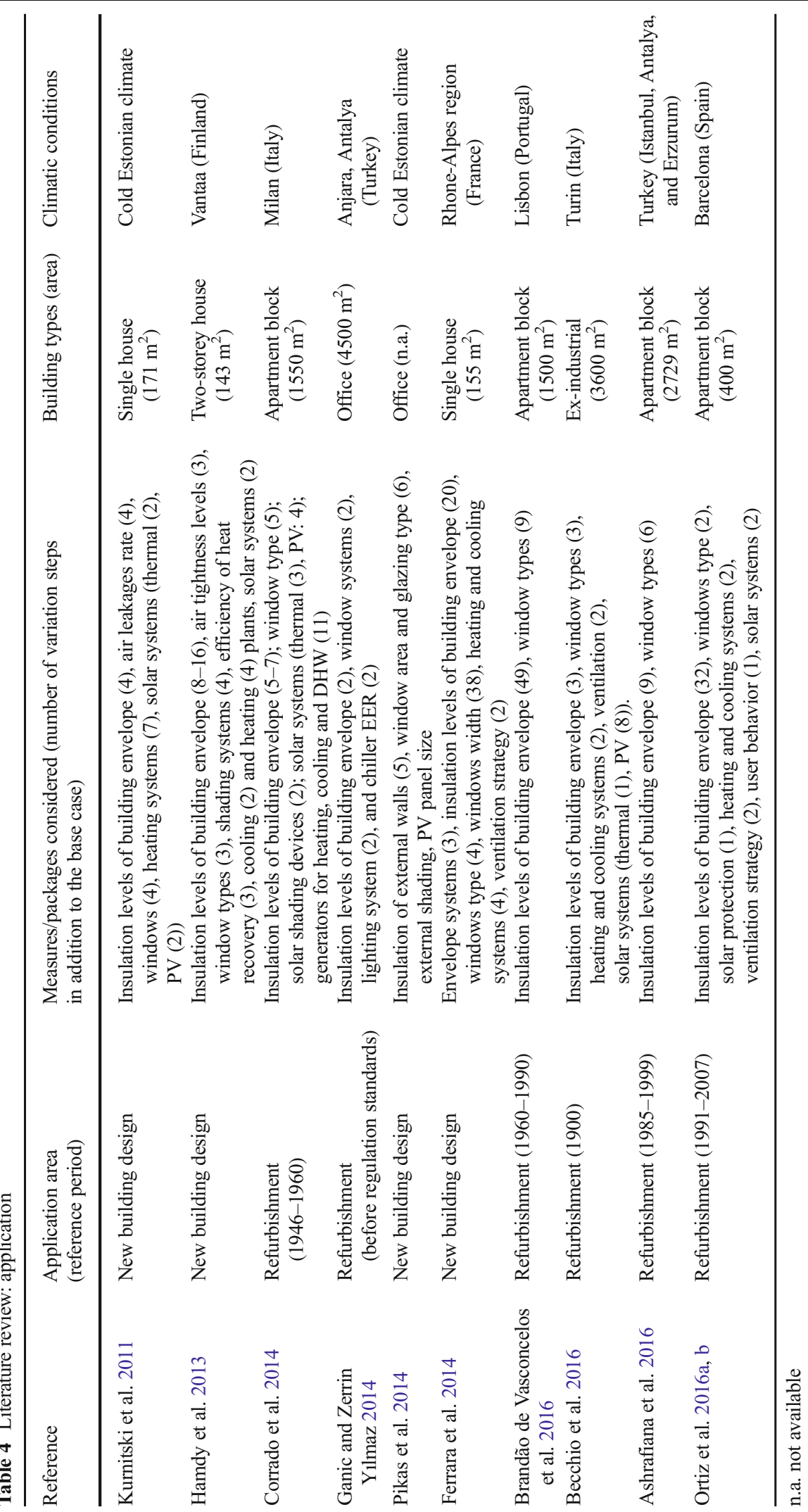


Table 5 Summary of the applied methodology

\begin{tabular}{|c|c|c|}
\hline \multirow[t]{4}{*}{ Applied methodology } & Calculation of energy needs & Dynamic simulation with EnergyPlus \\
\hline & Calculation of final Energy uses & $\begin{array}{l}\text { Applying simplified and auxiliary design } \\
\text { calculations }\end{array}$ \\
\hline & Solving method & $\begin{array}{l}\text { Combination of the considered measures/ } \\
\text { packages }\end{array}$ \\
\hline & Number of building variants & $>25,000$ \\
\hline \multirow[t]{4}{*}{ Energy calculation } & Energy uses considered & $\begin{array}{l}\text { Heating, cooling, ventilation, pumps and fans, } \\
\text { other technical service systems, DHW, lighting }\end{array}$ \\
\hline & Electric primary energy factor & $\begin{array}{l}\text { Between } 1.50 \text { and } 3.14 \text {, depending on the national } \\
\text { mix of sources and generation technologies. } \\
\text { Evaluated for two scenarios (reference and } \\
\text { ambitious) in each considered national context }\end{array}$ \\
\hline & PV energy taken into account & $\begin{array}{l}\text { Self-consumed (by simplified assumptions) and } \\
\text { exported to the grid }\end{array}$ \\
\hline & T set-points in winter and summer & $20^{\circ} \mathrm{C}-26^{\circ} \mathrm{C}$ \\
\hline \multirow[t]{5}{*}{ Global cost calculation } & Considered costs & $\begin{array}{l}\text { Energy, labor, materials, maintenance, replacement, } \\
\text { disposal and taxes }\end{array}$ \\
\hline & Economic perspective & Financial and macroeconomic \\
\hline & Building's lifetime & 30 years \\
\hline & Real interest rate & $\begin{array}{l}\text { Between } 0.86 \text { and } 2.36 \% \text {, depending on the } \\
\text { national context (from EUROSTAT 2008-2011) }\end{array}$ \\
\hline & Annual increase of energy prices & $\begin{array}{l}\text { Patterns simulated over the period 2011-2050 for } \\
\text { two energy scenarios ("Reference" and "Ambitious") }\end{array}$ \\
\hline \multirow[t]{4}{*}{ Application } & Application area & Refurbishment (of buildings built in $60 \mathrm{~s}-70 \mathrm{~s}$ ) \\
\hline & $\begin{array}{l}\text { Measures/packages considered } \\
\text { (variants in addition to the base } \\
\text { refurbishment case) }\end{array}$ & $\begin{array}{l}\text { Insulation levels of building envelope (3), tightness } \\
\text { levels (2), window types (2), shading systems } \\
\text { (1-2), night natural ventilation strategies (1-2), } \\
\text { lighting load/control (1-2), efficiency of heat recovery } \\
\text { (1), heating (5) and cooling (4) generators, heating } \\
\text { (1) and cooling (1) distribution, heating (4) and } \\
\text { cooling (4) emission systems, heating (1) and cooling } \\
\text { (2) control, solar systems (3) }\end{array}$ \\
\hline & Building types (area) & $\begin{array}{l}\text { Single house }\left(140 \mathrm{~m}^{2}\right) \text {, apartment block }\left(1000 \mathrm{~m}^{2}\right) \text {, office } \\
\quad\left(2400 \mathrm{~m}^{2}\right), \text { school }\left(3500 \mathrm{~m}^{2}\right)\end{array}$ \\
\hline & Climatic conditions & $\begin{array}{l}\text { Seville (ES), Madrid (ES), Rome (IT), Milan (IT), } \\
\text { Bucharest (RO), Vienna (AT), Paris (FR), Prague (CZ), } \\
\text { Berlin (DE), Helsinki (FI) }\end{array}$ \\
\hline
\end{tabular}

stage (it considers in one single step all the technologies and their combinations, rather than optimizing step by step); (ii) it describes the entire Energy-Cost plane rather than being limited to the Pareto frontier; (iii) it computes a large number of variants, thus avoiding to rely on a pre-judgment from the analyst of the suitable combinations which might miss some relevant variant; and iv) it includes a base refurbishment level as a useful reference for the entire energy and cost calculation.

To populate a large database of comparable results across Europe, the calculation is applied to four building types (two residential and two non-residential), representative of the EU stock built in years ' $60-$ ' 70 , in ten European climatic contexts.
The rest of this paper is structured as follows: "Methodology" section describes the calculation methodology and the main input data used. "Results and discussion" section presents and discusses the main results obtained. Finally, the most relevant conclusions are outlined in "Conclusions" section.

\section{Methodology}

To identify cost-optimal benchmarks for building renovations across Europe, a comprehensive methodology was developed. It consists of seven steps, starting from the selection of reference climates in EU28 and ending 

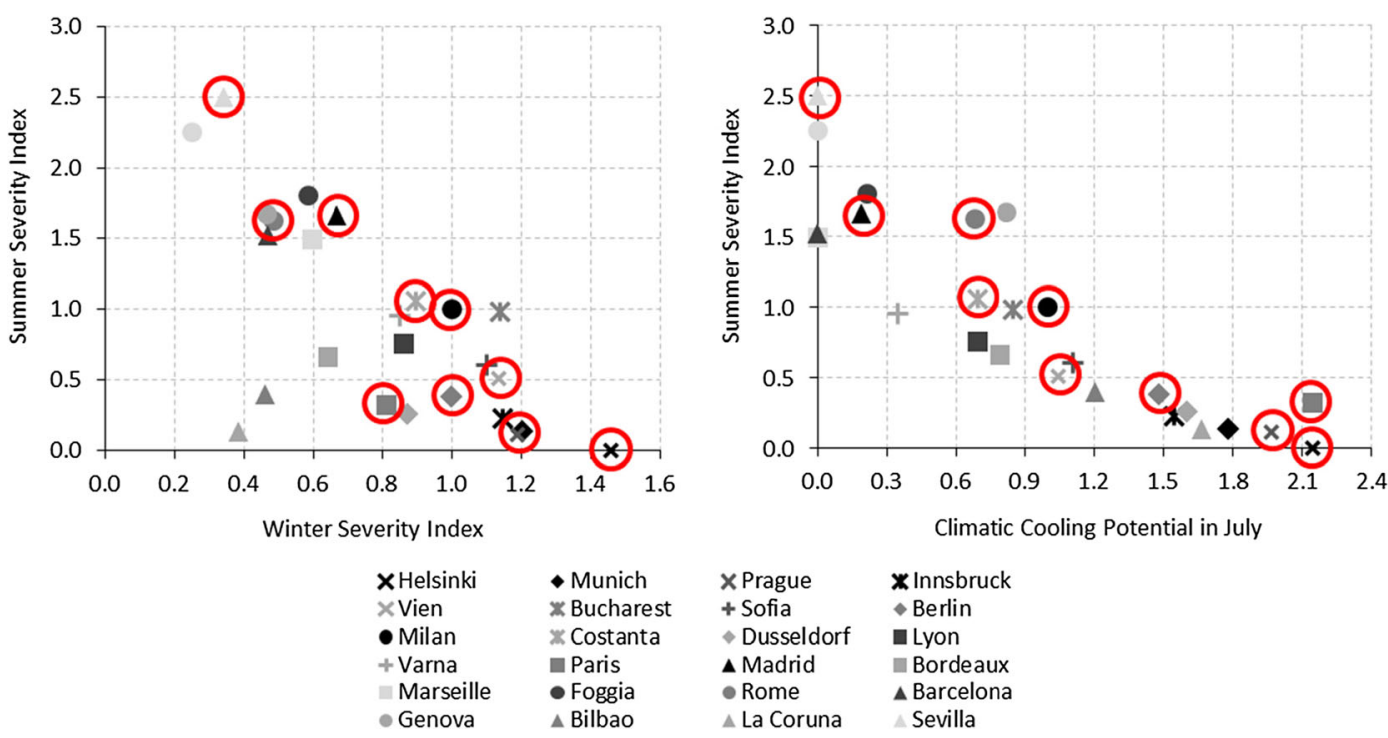

Fig. 1 Summer Severity Index versus Winter Severity Index (on the left) and Climatic Cooling Potential in July (on the right) for 24 European cities (values normalized on those of Milan) with indication (red circles) of the ones selected for this analysis

with the development of a sensitivity analysis. In general, the methodology of the study is as follows:

- Step 1: selection of representative climate conditions within the European Union.

- Step 2: definition of reference building types (including its thermos-physical, passive and active components) and determination of base levels of retrofit measures.
- Step 3: selection of renovation measures and packages applicable to the building types.

- Step 4: execution of energy calculations for each combination of retrofit measures, with the determination of the (net) primary energy demand.

- Step 5: execution of economic calculations for each combination of retrofit measures, determining the investments costs and the global costs over the calculation period.
Fig. 2 Schedules used to simulate the internal gains in the building types
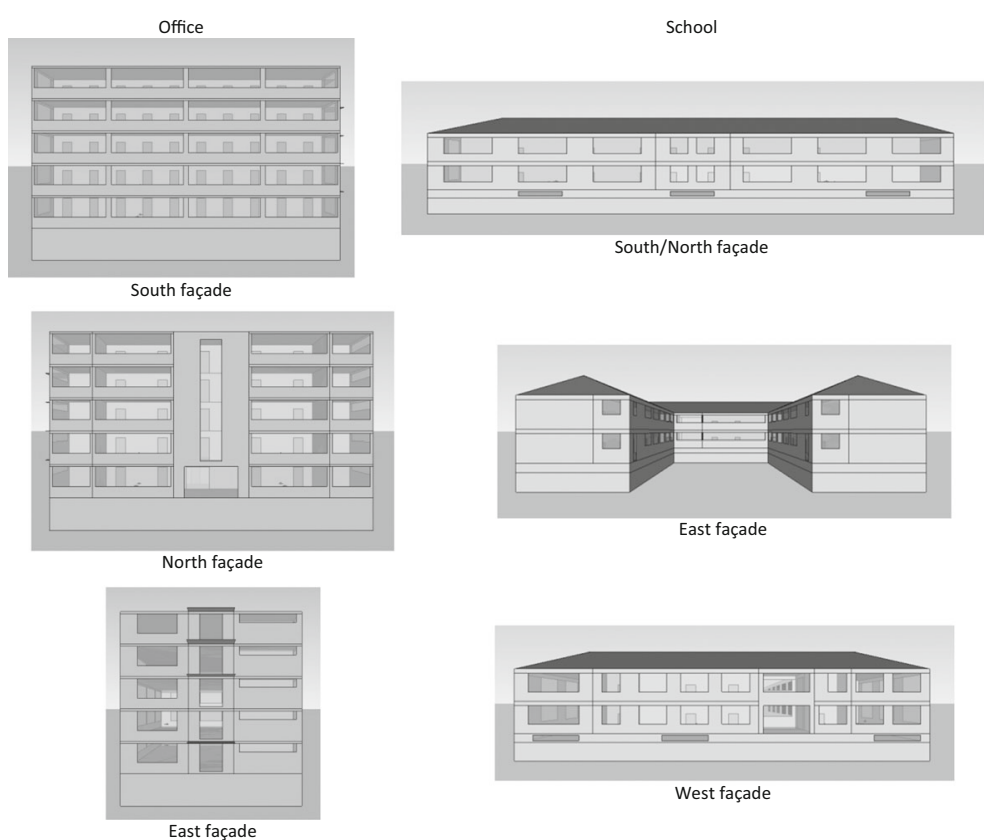
- Step 6: identification of energy levels representing the cost-optimal and the NZEB targets and optimum packages of retrofit measures (i.e., technological benchmarks).

- Step 7: development of a sensitivity analysis focused on some key calculation parameters.

To provide a comparison with the bibliography discussed in the introduction, a summary of the methodology applied in this study is shown in Table 5. The following subchapters provide more details about the main steps of the calculation approach.

\section{Selecting the EU reference climates}

The climate of Europe is temperate-continental, with the influence of the ocean on the western coasts and a Mediterranean climate in the South. The climate is strongly influenced by the Gulf Stream, which keeps mild air over the high-latitude north-western region over the winter months. While Western Europe has an oceanic climate, Eastern Europe has a drier, continental climate. Parts of the Central European plains have a hybrid oceanic/continental climate. Four seasons occur in Eastern Europe, while Southern Europe experiences distinct wet season and dry seasons, with prevailing hot and dry conditions during the summer months.

To assess the energy and comfort performances of buildings, climatic conditions are usually represented as sets of data that describe the climate at a certain location at different degrees of detail. Since several weather variables affect the building behavior, it is not straightforward to establish a definition of typical weather. Different definitions and hence different types of data sets are available based on different weighting of the parameters and other choices. In this case, the analysis was based on the datasets developed by the International Weather for Energy Calculations (IWEC), ${ }^{5}$ which consist in hourly data of the main climatic variables arranged in typical weather years. This same data was subsequently used to carry out the energy simulations.

To take into account the climatic variety of the EU28 area, nine target European countries were chosen. Within them, the climatic conditions of 24 cities were chosen for

\footnotetext{
${ }^{5}$ The IWEC weather files are the result of the ASHRAE Research Project 1015 by Numerical Logics and Bodycote Materials Testing Canada for ASHRAE Technical Committee 4.2 Weather Information. They were derived from up to 18 years of DATSAV3 hourly weather data.
}

their representativeness. To further filter the selection, three indicators were used as reference: the Winter Severity Index and the Summer Severity Index proposed by F. Sanchez de la Florthe (2006) and the Climatic Cooling Potential developed by Artmann et al. (2007). These indexes were calculated for all cities (Fig. 1), and ten of them were finally chosen also depending on their relevance in terms of urban population. Finally, the following climate conditions were selected: Seville (ES), Madrid (ES), Rome (IT), Milan (IT), Bucharest (RO), Vienna (AT), Paris (FR), Prague (CZ), Berlin (DE), and Helsinki (FI).

Defining the reference building types

According to the Building Stock Observatory of the European Commission, ${ }^{6}$ in 2013 , the EU residential stock (which accounts for about $65 \%$ of consumption) is composed by almost 250 million of dwellings (singlefamily houses represent $65 \%$ of residential floor space, against $35 \%$ for apartments), of which almost $43 \%$ built in the period 1945-1979. Out of the total floor area of the service sector, $29 \%$ is used for offices (public and private), $27.5 \%$ for wholesale and trade, $16 \%$ for educational activities, $14.5 \%$ for hotels and restaurants and $6.5 \%$ for health and medical activities, and the remaining $6.5 \%$ for other activities.

In this context and in line with the principles of the EPBD Directive, four typologies of buildings (two residential and two examples of the non-residential sector) were selected. The attention was focused on the relevant and strategic subcategory of buildings built in the $60 \mathrm{~s}-$ 70 s, before the appearance of significant energy performance requirements in the European and national regulations. To establish models representative of the national building stocks and, at the same time, to allow a direct cross comparison between countries, it was decided to fix the envelope geometries and the internal gains. Taking into account the data collected by previous studies (Tabula: Ballarini et al. 2014; Corgnati et al. 2013; Odyssee-Mure: Lapillonne et al. 2012) and asking the advice of national experts participating to the research project ENTRANZE, these reference cases were obtained:

- a single (detached) house, composed by two floors over the ground level and an underground level, with a net conditioned area of about $140 \mathrm{~m}^{2}$ and a

\footnotetext{
${ }^{6} \mathrm{http} / /$ ec.europa.eu/energy/en/eu-buildings-database
} 
Table 6 Fixed building characteristics of the selected reference buildings

\begin{tabular}{|c|c|c|c|c|c|}
\hline & Building characteristic & $\begin{array}{l}\text { Single-family } \\
\text { house (SFH) }\end{array}$ & Apartment block (AB) & Office & School \\
\hline \multirow{12}{*}{$\begin{array}{l}\text { Building } \\
\text { geometry }\end{array}$} & No. of heated floor & 2 & 4 & 5 & 2 \\
\hline & $S / V$ ratio $\left(\mathrm{m}^{2 /} \mathrm{m}^{3}\right)$ & 0.7 & 0.33 & 0.33 & 0.46 \\
\hline & Main orientation & $\mathrm{S} / \mathrm{N}$ & $\mathrm{S} / \mathrm{N}$ & $\mathrm{S} / \mathrm{N}$ & $\mathrm{S} / \mathrm{N}$ \\
\hline & Net dimensions of heated volume & $8.5 \times 8.5 \times 6 \mathrm{~m}$ & $24.6 \times 11.2 \times 12.8 \mathrm{~m}$ & $30 \times 16 \times 15 \mathrm{~m}$ & $\begin{array}{c}45 \times 60 \times 7 \mathrm{~m} \\
(\mathrm{U} \text { shape })\end{array}$ \\
\hline & Net floor area of heated zones $\left(\mathrm{m}^{2}\right)$ & 140 & 990 & 2400 & 3500 \\
\hline & Area of $\mathrm{S}$ and $\mathrm{N}$ façade $\left(\mathrm{m}^{2}\right)$ & 51 & 315 & 450 & 752.5 \\
\hline & Area of $\mathrm{E}$ and $\mathrm{W}$ façade $\left(\mathrm{m}^{2}\right)$ & 51 & 143 & 240 & 315 \\
\hline & Area of the roof/basement $\left(\mathrm{m}^{2}\right)$ & 72.25 & 54 & 480 & 1750 \\
\hline & Window area on S façade (\%) & 25 & $15-30$ & 56 & 32 \\
\hline & Window area on E façade (\%) & 7 & 0 & 32 & 22 \\
\hline & Window area on $\mathrm{N}$ façade $(\%)$ & 25 & $15-30$ & 50 & 29 \\
\hline & Window area on $\mathrm{W}$ façade $(\%)$ & 7 & 0 & 35 & 40 \\
\hline \multirow{3}{*}{$\begin{array}{l}\text { Internal gains } \\
\quad \text { (main rooms) }\end{array}$} & Occupancy design level ( $\mathrm{m}^{2} /$ person$)$ & 50 & 25 & 18 & 5.6 \\
\hline & Lighting design level $\left(\mathrm{W} / \mathrm{m}^{2}\right)$ & 3.5 & 3.5 & 18 & 18 \\
\hline & Appliances design level (W/m²) & 4 & 4 & 9 & 1.75 \\
\hline
\end{tabular}

ratio of envelope area and conditioned net volume $(S / V$ ratio) of 0.7 ,

- a four-floor block of 12 apartments with a conditioned area of $1000 \mathrm{~m}^{2}$ and a $S / V$ ratio of 0.33 ,

- a medium-size and highly glazed office building, with five floors (of 3-m height each), $S / V$ ratio of 0.33 and a net heated area of $2400 \mathrm{~m}^{2}$ (prospects shown in Fig. 2), and

- a two-floor school of medium size with $S / V$ ratio of 0.46 and a net heated area of $3500 \mathrm{~m}^{2}$ (Fig. 2).

Additional details about these types are provided in Table 6. Under the ground floors of all the reference buildings, there is an unconditioned basement. The residential models, as well as the school, have an unconditioned space between the last slab and the slope roof. Only for the apartment block, different window areas were selected in different climates: $15 \%$ of the total façade surface for the Spanish, Italian, and French cases; and $30 \%$ in the other countries.

To simulate the internal gains, typical design levels and schedules were applied (Fig. 3). They were defined mediating the slightly different indications provided by the national experts, who referred to national standards or previous studies. A more precise method was used for the lighting loads in the non-residential buildings, where the switching on the lights was simulated dynamically to
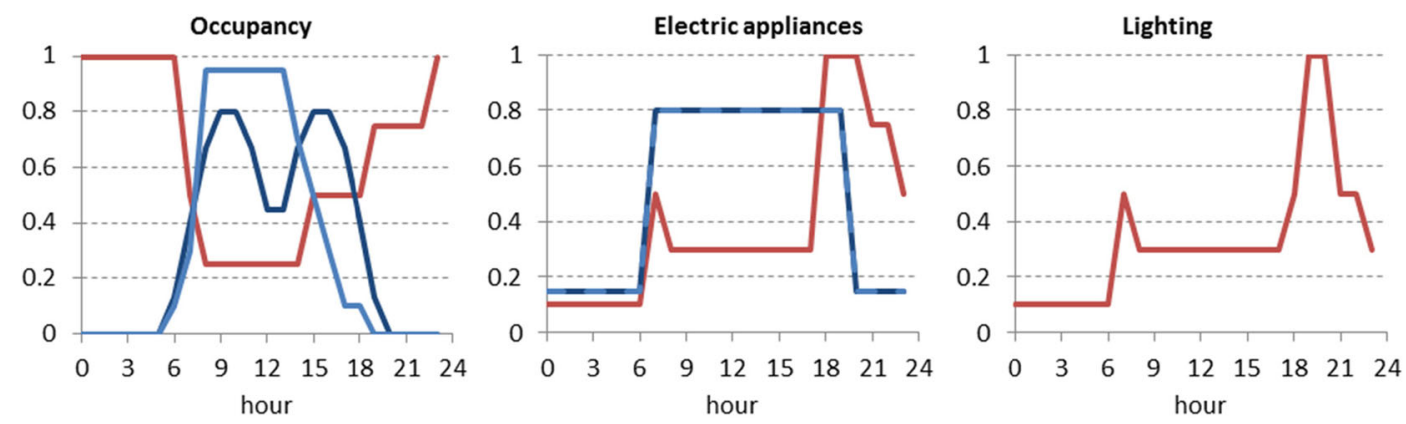

Residential (SFH and $\mathrm{AB}$ )
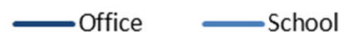

Fig. 3 Prospects of the non-residential building models 


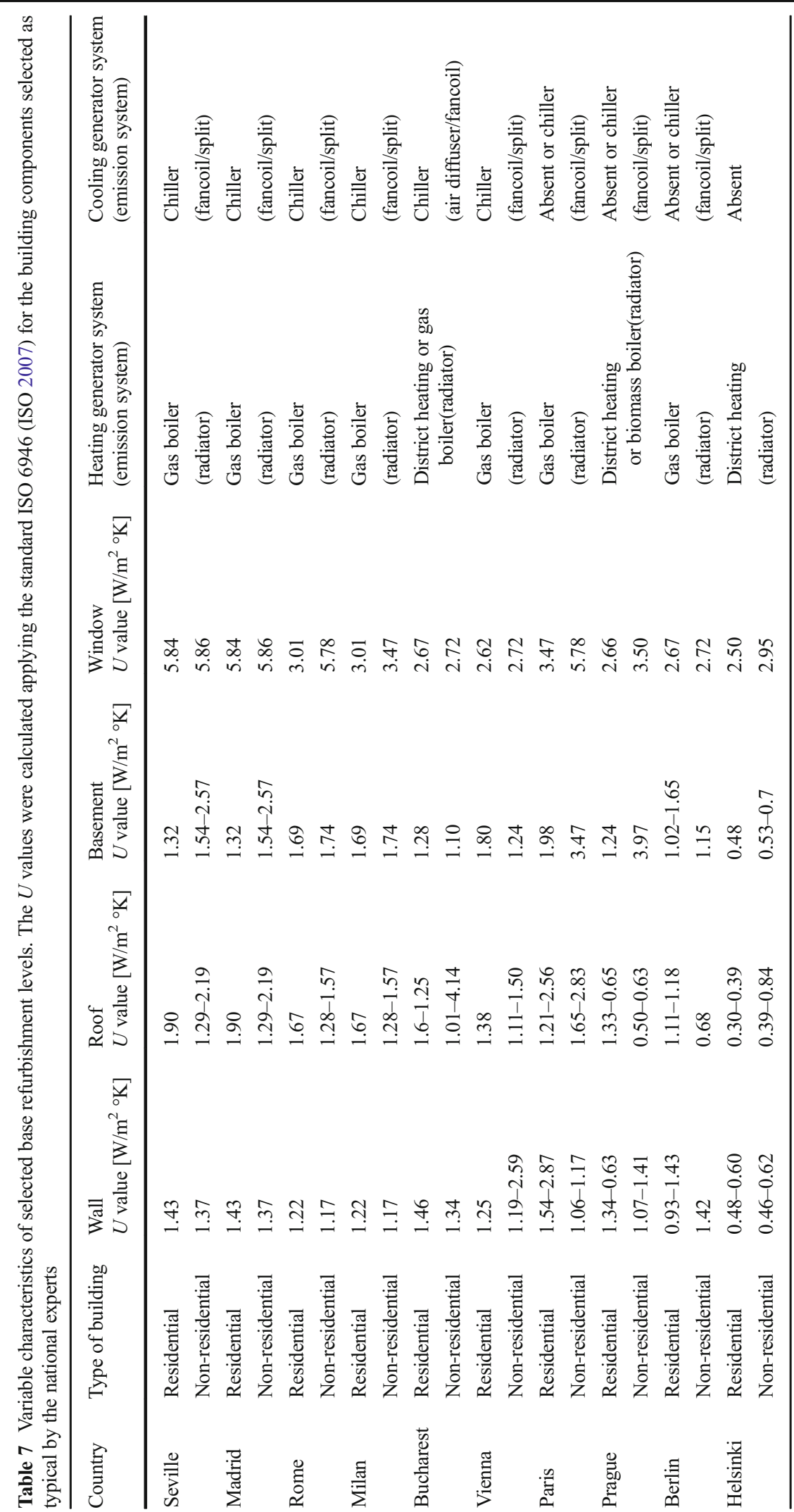


Table 8 Ranges of envelope variants selected for the residential type in the considered contexts

\begin{tabular}{|c|c|c|c|c|c|}
\hline Packages & Building parameter & $\begin{array}{l}\text { Base renovation } \\
\text { level } \\
\text { Value range }\end{array}$ & $\begin{array}{l}\text { Variation } \\
\text { step } 1 \\
\text { Value range }\end{array}$ & $\begin{array}{l}\text { Variation } \\
\text { step } 2 \\
\text { Value range }\end{array}$ & $\begin{array}{l}\text { Variation } \\
\text { step } 3 \\
\text { Value range }\end{array}$ \\
\hline \multirow{3}{*}{$\begin{array}{l}\text { Opaque envelope } \\
\text { elements }\end{array}$} & $U$ value of external walls $\left[\mathrm{W} / \mathrm{m}^{2}{ }^{\circ} \mathrm{K}\right]$ & $0.48-2.87$ & $0.22-0.52$ & $0.17-0.31$ & $0.15-0.23$ \\
\hline & U-value of Roof $\left[\mathrm{W} / \mathrm{m}^{2}{ }^{\circ} \mathrm{K}\right]$ & $0.3-2.56$ & $0.14-0.56$ & $0.12-0.33$ & $0.09-0.23$ \\
\hline & $U$ value of basement $\left[\mathrm{W} / \mathrm{m}^{2}{ }^{\circ} \mathrm{K}\right]$ & $0.48-1.98$ & $0.45-0.57$ & $0.29-0.48$ & $0.21-0.48$ \\
\hline \multirow[t]{2}{*}{ Window systems } & $U$ value of windows $\left[\mathrm{W} / \mathrm{m}^{2}{ }^{\circ} \mathrm{K}\right]$ & $2.5-5.84$ & $1.03-2.6$ & $0.7-1.71$ & - \\
\hline & $\begin{array}{l}\text { Infiltration air change rate per hour } \\
{[[1 / \mathrm{h}]}\end{array}$ & $0.27-0.77$ & $0.11-0.61$ & $0.08-0.58$ & - \\
\hline \multirow[t]{3}{*}{$\begin{array}{l}\text { Passive cooling } \\
\text { strategies }\end{array}$} & Solar shading device and control & $\begin{array}{l}\text { External blinds } \\
\text { manual }\end{array}$ & $\begin{array}{l}\text { External blinds } \\
\text { automated }\end{array}$ & - & - \\
\hline & Night ach ventilation rate $[1 / \mathrm{h}]$ & 0 & 4 & - & - \\
\hline & Lighting load $\left[\mathrm{W} / \mathrm{m}^{2}\right]$ and control & 3.5 manual & 3.5 manual & - & - \\
\hline Heat recovery & Efficiency [\%] & 0 (absent) & 80 & - & - \\
\hline
\end{tabular}

${ }^{\text {a }}$ Here, the actual average air changes per hour due to infiltrations are provided. They refer to three different permeability classes of windows (i.e., 2, 3, and 4), as defined by the European standard EN 12207 (CEN 2000)

achieve a specified illuminance set-point on the visual task (i.e., $750 \mathrm{~lx}$ ).

In order to obtain homogeneous building variants in terms of functionality, esthetic aspect, and liveability (conditions normally not evaluated by a cost-optimal analysis), the concept of "base refurbishment level" (BRL) was introduced. It represents the lower level of renovation to which compare the more efficient ones. In other words, it is not contemplated the possibility of not intervening in any way on a building older than 40 years. Avoiding to consider the renovation of building elements without an influence on the thermal energy needs, the BRL includes the rehabilitation of the building façade and roof (finishing material), the substitution of the old window systems and of the old heating/cooling systems with similar (in terms of technology) components, and the installation of an active cooling system (to guarantee similar thermal comfort conditions, if necessary ${ }^{7}$ ). This methodological refinement (the Commission's Guidelines do not require explicitly to define this refurbishment level) allows to clearly recognize also which costs could be omitted ${ }^{8}$ and to fix the end-life of the original building components (older than 40 years).

\footnotetext{
${ }^{7}$ The installation of an active cooling system was avoided only where the cooling power was lower than $5 \mathrm{~W} / \mathrm{m}^{2}$ or the cooling operation time was lower than $100 \mathrm{~h}$.

${ }^{8}$ Under the full cost approach disciplined by the reference guidelines, it results possible to omit the costs related to building elements which do not have an influence on the energy performance of the building and costs that are the same for all building variants.
}

Unlike geometries and thermal gains, the physical property of the envelope components (wall, roof, basement, windows) and the configurations of the thermal systems of the base cases (i.e., the base refurbishment levels) were diversified by country. They are shown in Table 7 .

Selecting the retrofit measures and calculating the associated energy levels

In order to define packages of measures able to increase the energy performances of the reference cases, technologies and techniques from the following groups were taken into account:

- Building envelope: measures that deal primarily with the reduction of heat transmission and improved air tightness of the building envelope with the objective of reducing transmission losses and losses from (uncontrolled) air-exchange.

- Space heating: an active system is usually necessary to meet the demand for heating. This demand can be met by efficient and/or renewable energy systems (e.g., condensing boilers, heat pumps, and thermal solar panels) in conjunction with suitable storage, distribution, and emission systems.

- Domestic hot water: DHW is often produced with the same system used for space heating, but it can also be supplied by combined systems (e.g., when integrating solar energy systems with a generator using fuel or electricity) or 
separate systems. High-efficient storage and distribution systems are crucial for reducing heat losses along all the chain.

- Ventilation systems: mechanical ventilation systems allow having control on the air change rates necessary for IAQ and can also limit losses from air-exchange if heat recovery systems are installed. Ventilation and heat recovery can have both a centralized or decentralized layout, with the latter sometimes easier to implement in retrofit work.

- Cooling: heat protection and passive cooling systems such as shading devices, night ventilation coupled with exposed mass, can help to reduce or avoid cooling needs to be met by active systems. Normally, these techniques are not considered in previous cost-optimal analysis, but their potential is relevant in many climates.

- Solar systems: photovoltaic and solar thermal systems are the most common technologies used to generate on-site renewable energy. Their contribution (also that exported to the grid) reduces the total primary energy demand.

- Lighting: for office and school buildings, in combination with adopted passive cooling strategies, energy efficiency actions were also adopted on lighting systems, particularly, high-efficiency lighting installations and automatic control as function of the daylighting illuminance levels and with objectives of glare reduction.

A relevant aspect of any cost-optimal calculation is the number of building variants that it can evaluate: on one hand, a low number allows very detailed calculations of the energy performances; on the other, a high one improves the characterization of the problem. In this case, to increase the number of variants evaluated with a reasonable level of detail, a three-step procedure was adopted for the primary energy demand calculations. In particular:

- firstly, the energy needs for heating and cooling, as well as the energy use for lighting (that also depends on the glazing typologies and solar shading solutions), were obtained by dynamic simulation of building models, suitably defined in EnergyPlus environment (United States Department of Energy 2013). 
Table 10 Summary of the boundary conditions of the simulations carried out

\begin{tabular}{|c|c|}
\hline EnergyPlus version & 7.2 \\
\hline $\begin{array}{l}\text { Surface convection } \\
\text { algorithm }\end{array}$ & Adaptive convection algorithm \\
\hline $\begin{array}{l}\text { Heat balance } \\
\text { algorithm }\end{array}$ & Conduction transfer function \\
\hline Solar Distribution & Full interior and exterior with reflections \\
\hline Terrain & City \\
\hline Zone thermal system & $\begin{array}{l}\text { Zone HVAC: ideal loads air system + } \\
\text { design specification: outdoor air }\end{array}$ \\
\hline Zone control & Humidistat and thermostat \\
\hline Daylighting object & Daylighting: controls \\
\hline $\begin{array}{l}\text { Infiltration and } \\
\text { ventilation objects }\end{array}$ & $\begin{array}{l}\text { Zone infiltration/ventilation: design flow } \\
\text { rate + zone refrigeration door mixing }\end{array}$ \\
\hline $\begin{array}{l}\text { Thermal bridge } \\
\text { adjustment }\end{array}$ & $\begin{array}{l}\text { Narrow sub-surfaces (as small part of the } \\
\text { external walls) were added for model- } \\
\text { ing lintels, columns and other main } \\
\text { thermal bridges. A no mass material } \\
\text { was associated to these geometric areas } \\
\text { and its fictitious U-value was calculated } \\
\text { on the basis of available thermal bridge } \\
\text { repertoires (Pascual Buisán et al. 2012). }\end{array}$ \\
\hline
\end{tabular}

- Secondly, the related final energy demands were calculated applying simplified dynamic calculations and/ or efficiency factors to each variant of the thermal subsystems and with further calculations for RES systems, pumps, fans, and other auxiliary systems.

- Finally, the net primary energy demand values were obtained applying appropriate primary energy conversion factors (PEFs), for which a dedicated study was developed, and (if applicable) subtracting the weighted contribution from solar renewable energy exported to the grid.

Combining the detailed dynamic simulations to obtain energy needs with the simplified design of thermal plants, more than 25 thousand building variants were defined, for each building type and each weather condition. In principle, this amount of data ensures the possibility of clearly recognizing the cost-optimal levels (minimum global cost for each value of net primary energy demand), as the lower profile of the "cloud" of points in the domain Energy-Cost. Multi-stage optimization approaches were not adopted to avoid limiting the economic competition between refurbishment measures related to different sub-systems of the building (e.g., between thermal insulation and RES systems).
Table 11 Ranges of efficiency coefficient considered for the subsystems alternatives

\begin{tabular}{|c|c|c|}
\hline \multirow[t]{2}{*}{ Sub-system } & \multicolumn{2}{|c|}{ Seasonal efficiency factor } \\
\hline & $\begin{array}{l}\text { In heating } \\
\text { mode }\end{array}$ & $\begin{array}{l}\text { In cooling } \\
\text { mode }\end{array}$ \\
\hline \multicolumn{3}{|l|}{ Generation systems } \\
\hline Gas boiler $(\%)$ & 80 & - \\
\hline Condensing gas boiler $(\%)$ & $95-104^{\mathrm{a}}$ & - \\
\hline $\begin{array}{l}\text { Air to water reversible heat pump } \\
\text { (with high SCOP/SEER) }\end{array}$ & $1.44-2.91^{\mathrm{b}}$ & $0.6-3.20^{\mathrm{b}}$ \\
\hline $\begin{array}{l}\text { Ground source reversible heat } \\
\text { pump (with high SCOP/SEER) }\end{array}$ & $1.55-3.89^{\mathrm{b}}$ & $0.63-4.45^{\mathrm{b}}$ \\
\hline District heating connection (\%) & 100 & - \\
\hline Biomass boiler $(\%)$ & 90 & - \\
\hline \multicolumn{3}{|l|}{ Emission systems } \\
\hline Insulated radiant floor $(\%)$ & $97-99^{\mathrm{c}}$ & 97 \\
\hline Radiator $(\%)$ & $92-95^{\mathrm{c}}$ & - \\
\hline Fancoil/split (\%) & $94-96^{\mathrm{c}}$ & 98 \\
\hline Air diffuser (\%) & $90-94^{\mathrm{c}}$ & 97 \\
\hline \multicolumn{3}{|l|}{ Distribution systems } \\
\hline Not insulated pipes $(\%)$ & $92-95^{\mathrm{a}}$ & $92-95$ \\
\hline Insulated pipes $(\%)$ & 99 & 99 \\
\hline \multicolumn{3}{|l|}{ Control systems } \\
\hline Climatic control system (\%) & $86-80^{\mathrm{a}}$ & 90 \\
\hline $\begin{array}{l}\text { Climatic + room indoor control } \\
\text { system }(\%)\end{array}$ & $98-95^{\mathrm{a}}$ & 98 \\
\hline \multicolumn{3}{|l|}{${ }^{\mathrm{a}}$ Depending on the emission system } \\
\hline \multicolumn{3}{|c|}{$\begin{array}{l}{ }^{\mathrm{b}} \text { Calculated for each building variant and climate according to } \\
\text { standard EN } 14825 \text { (2012) }\end{array}$} \\
\hline \multicolumn{3}{|c|}{${ }^{c}$ Depending on the emission power system } \\
\hline
\end{tabular}

\section{Energy performance of building envelope}

The selection of the energy efficiency measures is a critical choice since a very high number of packages can be established aggregating them. For this study, which provides a very wide application, the most typical and applicable renovation measures were selected and especially, those on the envelope (evaluated by dynamic simulation) were aggregated in several packages. Specifically, four packages of envelope measures were composed, combining the insulation of all the opaque envelope elements; the substitution of window systems (including glasses and frames); the heat protection and passive cooling strategies (including solar protections, night natural ventilation, and lighting); and the heat recovery strategy. As shown in Tables 8 and 9, in addition 
Table 12 Primary energy factor (PEF) considered for the present study

\begin{tabular}{|c|c|c|c|c|c|c|c|c|}
\hline Carrier & ES & IT & RO & AT & FR & $\mathrm{CZ}$ & $\mathrm{DE}$ & FI \\
\hline Electricity & 1.89 & 2.05 & 2.53 & 1.65 & 2.72 & 3.14 & 2.45 & 2.69 \\
\hline Gas & 1.00 & 1.00 & 1.00 & 1.17 & 1.00 & 1.00 & 1.00 & 1.00 \\
\hline Biomass (total PEF: renewable + non-renewable part) & 1.25 & 1.50 & 1.50 & 1.08 & 1.50 & 1.20 & 1.50 & 1.50 \\
\hline District heating & 1.20 & 1.20 & 1.20 & 1.00 & 1.20 & 1.40 & 1.20 & 0.70 \\
\hline
\end{tabular}

to the levels of the base cases, three levels of insulation, two types of windows, two passive cooling combinations, and one heat recovery strategy were identified for each building type and in each climate in accordance with the national experts' indications. Because these variants were defined as real retrofit measures (i.e., addition of an insulation layer of a certain commercial thickness and substitution of the window), the values of parameters depend on the starting characteristics of the reference models, which are different for every climatic context (as shown in Table 7).

Wishing to reduce the number of simulations, 36 of the possible 72 combinations of packages were selected renouncing to study seldom found renovation variants, such as those that provide a highperformance improvement of certain elements without a simultaneous action on the others (e.g., the installation of an insulating layer of $20-25 \mathrm{~cm}$, at same time maintaining the original single-panes glazing). In this way, a total of 1440 models (36 variants per 4 building types per 10 climates) were defined and their energy needs for heating/cooling and energy use for lighting were calculated by the EnergyPlus simulations.

For obtaining building envelope configurations fully comparable in terms of indoor comfort performances, the energy needs for all the building

Table 13 Average and standard deviation (on all target countries) of cost of technologies (material, labor, general expenditure, and business profit) for the different variation steps

\begin{tabular}{|c|c|c|c|c|c|c|}
\hline Packages & Building parameter & $\begin{array}{l}\text { Type of } \\
\text { building }\end{array}$ & $\begin{array}{l}\text { Base renovation } \\
\text { level } \\
\text { average } \pm \text { st. dev. }\end{array}$ & $\begin{array}{l}\text { Variation step } \\
1 \\
\text { average } \pm \text { st. } \\
\text { dev. }\end{array}$ & $\begin{array}{l}\text { Variation step } \\
2 \\
\text { average } \pm \text { st. } \\
\text { dev. }\end{array}$ & $\begin{array}{l}\text { Variation step } \\
3 \\
\text { average } \pm \text { st. } \\
\text { dev. }\end{array}$ \\
\hline \multirow{6}{*}{$\begin{array}{l}\text { Opaque envelope } \\
\text { elements }\end{array}$} & \multirow[t]{2}{*}{ Walls $\left[€ / \mathrm{m}^{2}\right]$} & Res. & $32 \pm 23$ & $64 \pm 20$ & $72 \pm 22$ & $80 \pm 23$ \\
\hline & & Non-res. & $31 \pm 22$ & $59 \pm 19$ & $70 \pm 24$ & $86 \pm 26$ \\
\hline & \multirow[t]{2}{*}{$\operatorname{Roof}^{\mathrm{b}}\left[€ / \mathrm{m}^{2}\right]$} & Res. & No renovation $^{\mathrm{a}}$ & $27 \pm 12$ & $32 \pm 11$ & $42 \pm 12$ \\
\hline & & Non-res. & $51 \pm 20$ & $54 \pm 48$ & $67 \pm 50$ & $80 \pm 52$ \\
\hline & \multirow[t]{2}{*}{ Basement $\left[€ / \mathrm{m}^{2}\right]$} & Res. & No renovation & $37 \pm 24$ & $43 \pm 24$ & $52 \pm 25$ \\
\hline & & Non-res. & No renovation & $52 \pm 27$ & $60 \pm 29$ & $69 \pm 30$ \\
\hline \multirow[t]{2}{*}{ Window systems } & \multirow[t]{2}{*}{ Window $^{\mathrm{c}}\left[€ / \mathrm{m}^{2}\right]$} & Res. & $64 \pm 29$ & $277 \pm 74$ & $332 \pm 96$ & - \\
\hline & & Non-res. & $64 \pm 26$ & $276 \pm 69$ & $329 \pm 84$ & - \\
\hline \multirow{6}{*}{$\begin{array}{l}\text { Passive cooling } \\
\text { strategies }\end{array}$} & \multirow{2}{*}{$\begin{array}{l}\text { Solar shading device and } \\
\text { control } \\
{\left[€ / \mathrm{m}^{2} \text { of windows }\right]}\end{array}$} & Res. & $201 \pm 119$ & $325 \pm 130$ & - & - \\
\hline & & Non-res. & $199 \pm 113$ & $319 \pm 124$ & $335 \pm 126$ & - \\
\hline & \multirow{2}{*}{$\begin{array}{l}\text { Night ventilation system } \\
{\left[€ / \mathrm{m}^{2} \text { of windows }\right]}\end{array}$} & Res. & Absent & $228 \pm 58$ & - & - \\
\hline & & Non-res. & Absent & $119 \pm 114$ & $222 \pm 56$ & - \\
\hline & \multirow{2}{*}{$\begin{array}{l}\text { Lighting and control } \\
{\left[€ / \mathrm{m}^{2} \text { of floor }\right]}\end{array}$} & Res. & - & - & - & - \\
\hline & & Non-res. & $33 \pm 12$ & $39 \pm 15$ & $69 \pm 18$ & - \\
\hline
\end{tabular}

\footnotetext{
${ }^{a}$ The rehabilitation of the finishing material of the roof do not have an influence on the thermal energy needs, because there is a unconditioned zone between the roof and the heated spaces

${ }^{\mathrm{b}}$ In school building, last slab in contact with unconditioned space; in office, roof in contact with conditioned space

${ }^{\mathrm{c}}$ Variant 1: repair and restoration existing windows
} 
Table 14 Average and standard deviation (on all target countries) of cost of sub-systems alternatives (material, labor, general expenditure, and business profit)

\begin{tabular}{|c|c|c|}
\hline Sub-system & Unit & Average \pm st. dev. \\
\hline \multicolumn{3}{|l|}{ Generation systems } \\
\hline Gas boiler & $€ / \mathrm{kW}$ & $151 \pm 72$ \\
\hline Condensing gas boiler & $€ / \mathrm{kW}$ & $194 \pm 90$ \\
\hline $\begin{array}{l}\text { Air to water reversible heat pump } \\
\text { (with high SCOP/SEER) }\end{array}$ & $€ / \mathrm{kW}$ & $524 \pm 209$ \\
\hline $\begin{array}{l}\text { Ground source reversible heat pump } \\
\text { (with high SCOP/SEER) }\end{array}$ & $€ / \mathrm{kW}$ & $1009 \pm 325$ \\
\hline District heating connection & $€ /$ dwelling & $642 \pm 240$ \\
\hline Biomass boiler & $€ / \mathrm{kW}$ & $541 \pm 108$ \\
\hline \multicolumn{3}{|l|}{ Emission systems } \\
\hline Insulated radiant floor & $€ / \mathrm{m}^{2}$ of floor & $92 \pm 68$ \\
\hline Insulated radiant floor + local dehumidifier & $€ / \mathrm{m}^{2}$ of floor & $141 \pm 68$ \\
\hline Radiator & $€ / \mathrm{m}^{2}$ space conditioned & $45 \pm 31$ \\
\hline Fancoil/split & $€ / \mathrm{m}^{2}$ space conditioned & $54 \pm 27$ \\
\hline Air diffuser & $€ / \mathrm{m}^{2}$ space conditioned & $73 \pm 30$ \\
\hline \multicolumn{3}{|l|}{ Distribution systems } \\
\hline Insulated pipes (low) & $€ / \mathrm{m}$ of pipe & $8 \pm 4$ \\
\hline Insulated pipes (medium) & $€ / \mathrm{m}$ of pipe & $12 \pm 6$ \\
\hline \multicolumn{3}{|l|}{ Control systems } \\
\hline Climatic control system & $€ /$ unit & $996 \pm 456$ \\
\hline Climatic + room indoor control system & $€ /$ number of rooms & $311 \pm 168$ \\
\hline \multicolumn{3}{|l|}{ Solar systems } \\
\hline Photovoltaic panels & $€ / \mathrm{m}^{2}$ of solar panel & $2782 \pm 386$ \\
\hline Solar thermal system & $€ / \mathrm{m}^{2}$ of solar panel & $812 \pm 378$ \\
\hline
\end{tabular}

variants were calculated assuming the same indoor conditions for each typology, specifically, the same operative temperature and relative humidity setpoints, $20{ }^{\circ} \mathrm{C}$ in winter and $26{ }^{\circ} \mathrm{C}$ in summer (latent control not applied) for the residential types and $20{ }^{\circ} \mathrm{C}$ and $25 \%$ in winter and $26{ }^{\circ} \mathrm{C}$ and $60 \%$ in summer for the non-residential buildings 9 . The same was done for the values of minimum air change (at maximum occupation rate), coherently with the occupation levels and the ventilation design rates proposed by EN 15251 (CEN 2007b) for very lowpolluted buildings, $0.5 \mathrm{~h}^{-1}$ in the residential buildings, $0.8 \mathrm{~h}^{-1}$ in the office, and $1.6 \mathrm{~h}^{-1}$ in the school.

\footnotetext{
$\overline{9}$ As discussed in several previous studies (Nicol and Humphreys 2010; Deuble and de Dear 2012; Pagliano and Zangheri 2010; Carlucci 2013), other choices (e.g., the adaptive comfort target for naturally ventilated buildings) are also possible and it may be one of the ways to reduce the energy needs for cooling with respect to those estimated in this study, while offering comfortable living and working conditions to occupants.
}

About the tool employed for this first step of calculation, it is useful to specify the algorithms used, the boundary condition selected, and the choices made to overcome some limitations of the software (as the evaluation of the thermal bridges). An overview of these aspects is shown in Table 10.

\section{Energy performance of thermal systems}

The thermal systems (including all the main subcomponents) were evaluated by simplified calculation methods derived from the Italian EPB standard UNI TS 11300-2 (UNI 2008) and several European reference standards: EN 15243 (CEN 2007a), EN 15316 (CEN 2007c), and EN 14825 (CEN 2012). In this way, it was possible to associate to each envelope variant a large number of alternative (and feasible) thermal plants. They were designed combining five heating and cooling generator types, two distribution variants, four heating and cooling emission systems, and two heating/cooling control options. These alternatives were considered in all 

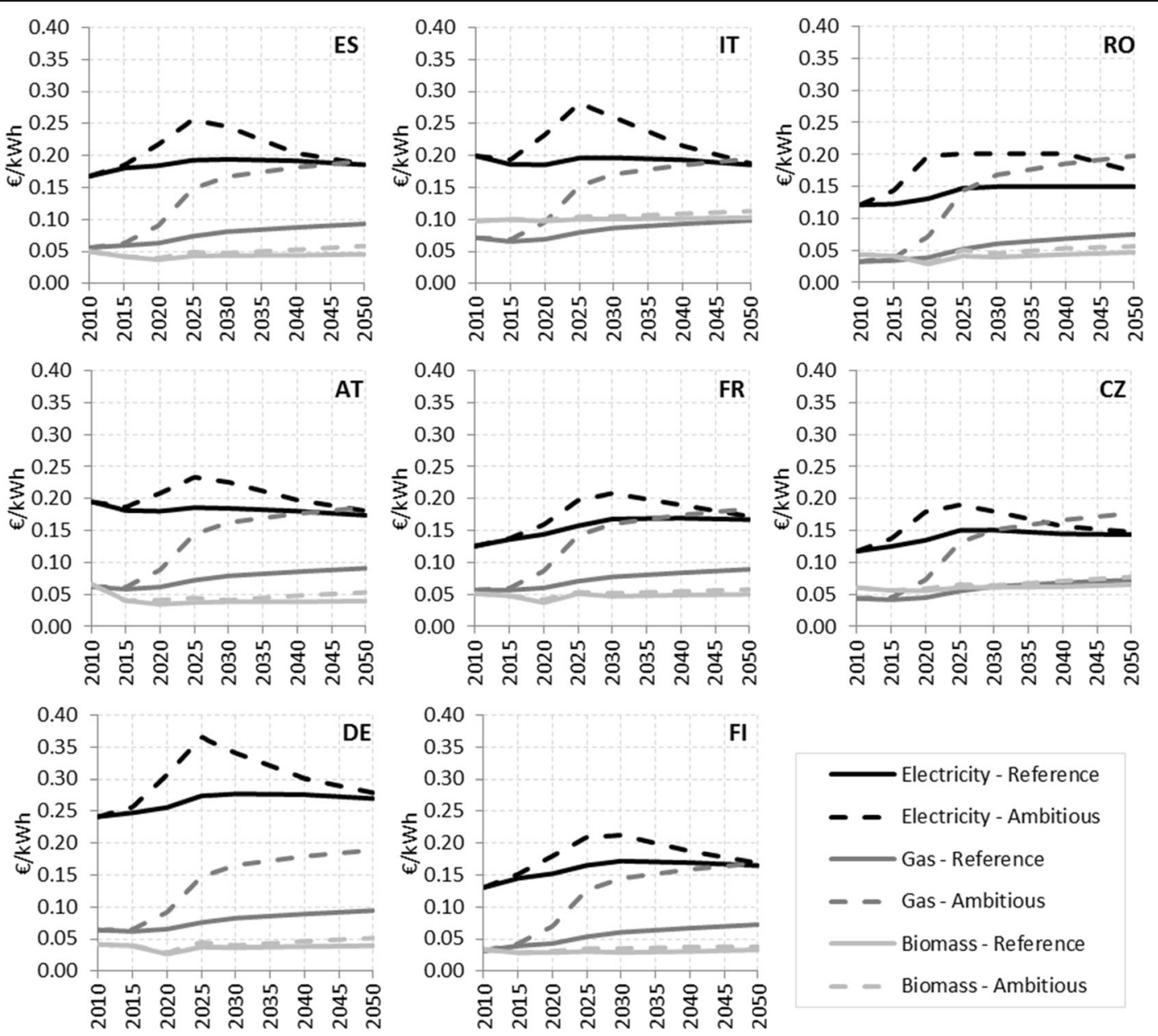

Fig. 4 Main energy prices estimated over the period 2010-2050 by POLES model, for the different macro-scenarios

selected contexts with some exceptions: the gas generation and the radiant floor systems were not applied in Finland, and the district heating option was not considered in Spain, due to their very low diffusion (also in the main urban areas).

In the assessment of the final energy demands, several auxiliary design calculations were also needed. Specifically, the seasonal efficiency factor of heat pumps was calculated applying the hourly method described in the standard EN 14825 (CEN 2012). The energy demand for DHW was estimated with the method EN 15316-3-1 (CEN 2005) and considering the number of occupants already used (as thermal gains) in the dynamic simulations.

Where applicable, the energy consumption of circulating pumps (ST included) was calculated assuming their efficiency equal to $80 \%$, estimating the pressure losses in function of the size and complexity of the different buildings and deducing the operation times from the simulation results (hourly energy needs). For the building variants in which a mechanical ventilation system was implemented, a simplified dimensioning of fan consumptions was based on an efficiency value of $60 \%$ and, in the presence of a heat exchanger, the pressure losses were increased of $300 \mathrm{~Pa}$. For fancoils and splits, a specific fan power of $0.7 \mathrm{~kW} / \mathrm{m}^{3} / \mathrm{s}$ was used. In designing the power of the auxiliary systems, a safety factor of 1.2 was used.

References on the variants of thermal system are provided in Table 11.

\section{Energy from RES}

In Europe, solar energy is one of the most favorable RES (European Commission 2006) and the most 
Table 15 Main economic inputs used in the cost-optimal calculations

\begin{tabular}{|c|c|c|c|c|c|c|c|c|}
\hline Economic parameters & ES & IT & RO & AT & FR & $\mathrm{CZ}$ & $\mathrm{DE}$ & FI \\
\hline Financial real interest rate $(\%)$ & 2.21 & 2.36 & 1.56 & 1.45 & 1.72 & 1.68 & 1.44 & 0.86 \\
\hline VAT —refurbishment of residential (\%) & 10.0 & 10.0 & 24.0 & 20.0 & 19.6 & 21.0 & 19.0 & 24.0 \\
\hline VAT—refurbishment of non-residential (\%) & 21.0 & 21.0 & 24.0 & 20.0 & 19.6 & 21.0 & 19.0 & 24.0 \\
\hline Taxes on electricity $(\%)$ & 19.4 & 28.3 & 19.4 & 27.2 & 29.4 & 17.5 & 44.6 & 29.8 \\
\hline Taxes on gas $(\%)$ & 15.3 & 36.4 & 47.6 & 25.6 & 16.6 & 16.7 & 24.2 & 36.9 \\
\hline Taxes on biomass $(\%)$ & 21.0 & 21.0 & 24.0 & 20.0 & 19.6 & 21.0 & 19.0 & 24.0 \\
\hline Taxes on district heating $(\%)$ & 21.0 & 21.0 & 24.0 & 20.0 & 19.6 & 21.0 & 19.0 & 29.0 \\
\hline Carbon price $(2011-2050) € / \mathrm{tCO}_{2}$ & \multicolumn{8}{|c|}{ From 3 (in 2011) to 84-493 (in 2050 for "Reference"-“Ambitious" scenarios) } \\
\hline
\end{tabular}

applied one to the building sector. The sun source was considered available on the roof of all building types, and four alternatives of solar systems were taken into account: (i) both solar thermal (ST) and photovoltaic (PV) absent; (ii) only solar thermal, designed to cover $50 \%$ of the energy need for hot water; (iii) only PV panels, installed on the $50 \%$ of the roof free surface (north exposition excluded) and designed to cover not more than the yearly primary energy demand of the building; and (iv) the combination of the two systems (with the previous sizing rules). A flat plate solar thermal collector ${ }^{10}$ and a photovoltaic panel of monocrystalline silicon ${ }^{11}$ were selected as reference technologies and fixed for all applications. A performance decay of $1 \%$ per year was applied for both technologies.

In line with the EU Commission Decision 2013/ 114/UE and the standard EN 15603 (CEN 2008), the renewable contribution from heat pumps and biomass generation systems was evaluated considering the first as "on-site generation from on-site renewables" and the second as "on-site generation from off-site renewables".

The electricity generated by photovoltaic systems and exported to the grid was converted in primary energy applying the same primary energy factors used to convert the electric final demand (see below).

\section{Primary energy of the building variant}

To obtain the (net) primary energy demand from the final levels, appropriate primary energy factors for each

\footnotetext{
${ }^{10}$ With: overall heat loss coefficient $\mathrm{U}_{\mathrm{L}}=3.5 \mathrm{~W} / \mathrm{m}^{2} \mathrm{~K}$; absorbance of the receiver $\alpha=0.95$; transmittance of the cover systems $\tau=0.85$.

${ }^{11}$ With peak power factor of $0.15 \mathrm{~kW} / \mathrm{m}^{2}$.
}

considered carrier were used (Table 12). For the primary energy factors of fossil sources, biomass, and district heating, the reference values provided by the national experts were applied. Otherwise, for electricity, a dedicated analysis was developed by Enerdata using the Prospective Outlook on Long-term Energy Systems (POLES) model. ${ }^{12}$ Price and power mix projections were derived from two scenarios of the world energy systems simulated with the POLES model, using historical data up to 2011: a "Reference" scenario and an "Ambitious" climate scenario, with the same macroeconomic context and main differences on the carbon policies.

The "Reference" scenario assumes that, once the global recession is over, business as usual behavior is resumed rather quickly. Only on-going and already planned climate policies are taken into account, including the $20 \%$ emissions reduction in the European Union by 2020. It is assumed that no consensus is reached at international level and, after 2020 , it is assumed that additional energy and climate policies are adopted (EU reduces its emissions in 2050 by $50 \%$ compared to 1990 levels). Without a global agreement, these low-intensity and noncoordinated policies result in soaring $\mathrm{CO}_{2}$ emissions across the world and in emerging economies in particular. The future fuel mix is dominated by fossil fuels.

The "Ambitious" climate scenario shows a clear transition towards a long-term decarbonisation, with more ambitious efforts on energy efficiency and a real emergence of renewable technologies. Negotiations between advanced and emerging economies on climate change are eventually successful,

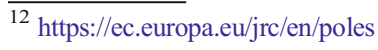




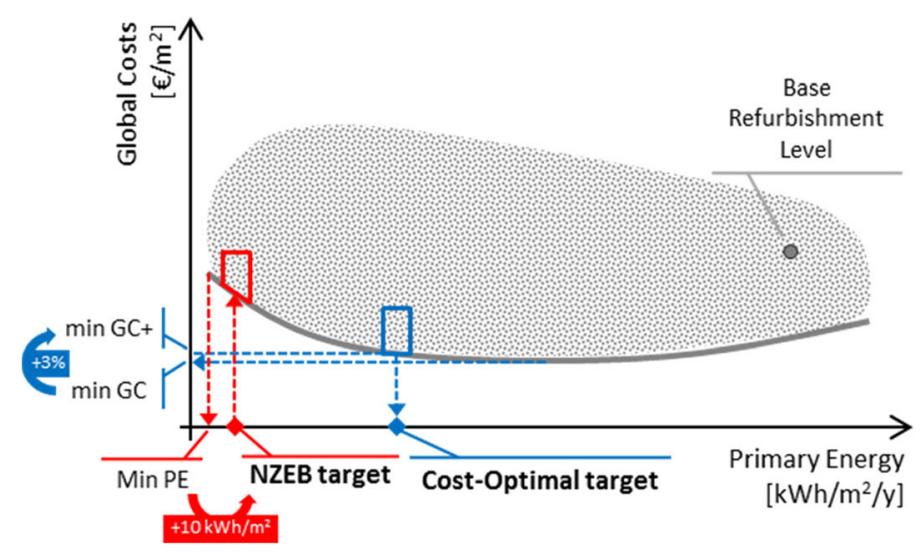

Cost-Optimal area

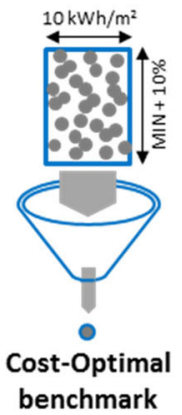

benchmark
NZEB area

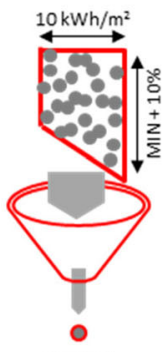

NZEB

benchmark

Fig. 5 Scheme of the methodology used for identifying the primary energy targets (on the left) and technological benchmarks (on the right) for a certain building type located in a certain climate

and an international consensus is progressively reached. Europe goes beyond its $-20 \%$ target by 2020, and the OECD and emerging countries meet their Copenhagen objectives. A new international agreement is adopted to reach the 2050 targets, i.e., a trajectory limiting the global temperature increase at around 2 to $3{ }^{\circ} \mathrm{C}$ by the end of the century (IPCC 2007), which implies reducing world emissions by a factor 2 by 2050 compared to 1990 levels, and by a factor of 4 for developed countries.
Under these assumptions, the residential domestic prices of oil and gas are projected to increase by respectively 5.9 and $5.2 \%$ per year in the ambitious scenario over the period 2010-2030. In the reference scenario, the progression will be lower because of lower carbon tax. The average electricity price will increase by $2 \%$ per year in the ambitious scenario and by $0.8 \%$ per year in the reference one. The electricity price is expected to peak in 2030 at around $\$ 3400 /$ toe in the ambitious scenario and at $\$ 2500 /$ toe in the reference scenario.

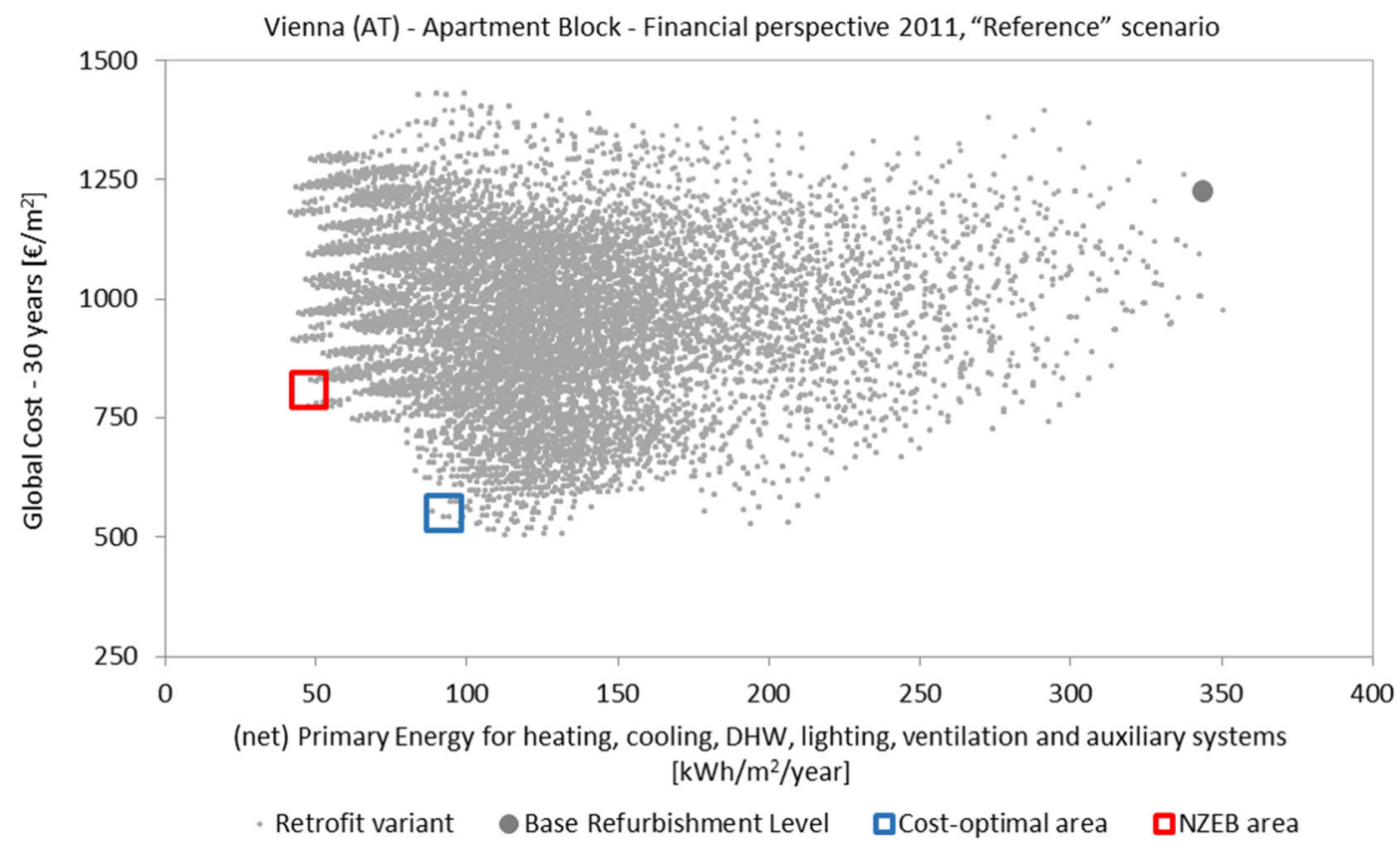

Fig. 6 Example of Energy-Cost cloud, obtained for the apartment block located in Vienna (financial perspective 2011, "Reference" scenario) 
Table 16 Identification of the cost-optimal ("C-opt”) and NZEB targets, and selection of technological benchmarks (financial perspective 2011, "Reference" scenario)

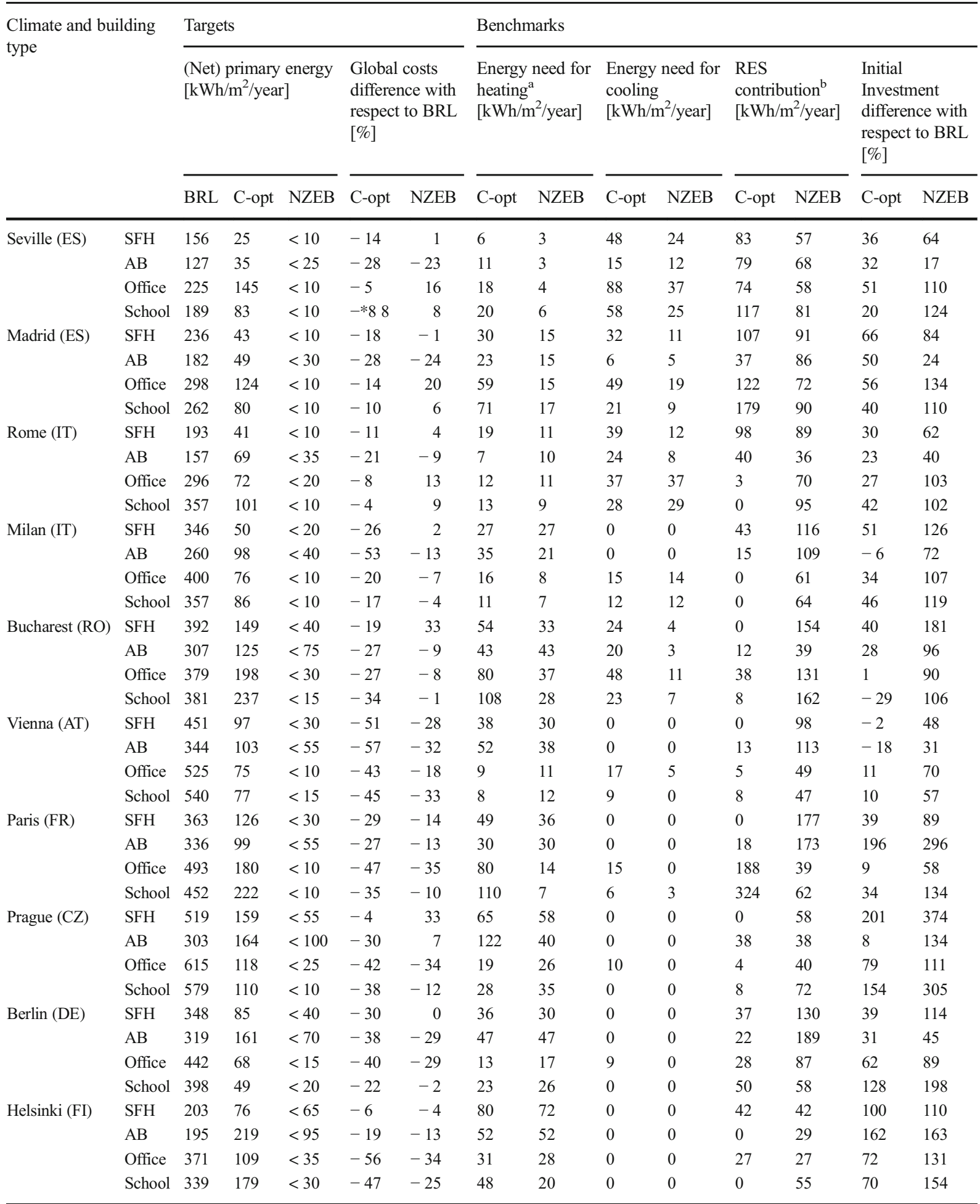

${ }^{a}$ If present, the reduction due to heat recovery strategies is taken into account

${ }^{\mathrm{b}}$ From thermal panels, PV systems and heat pumps, if present. This amount includes self-consumed and exported electricity 

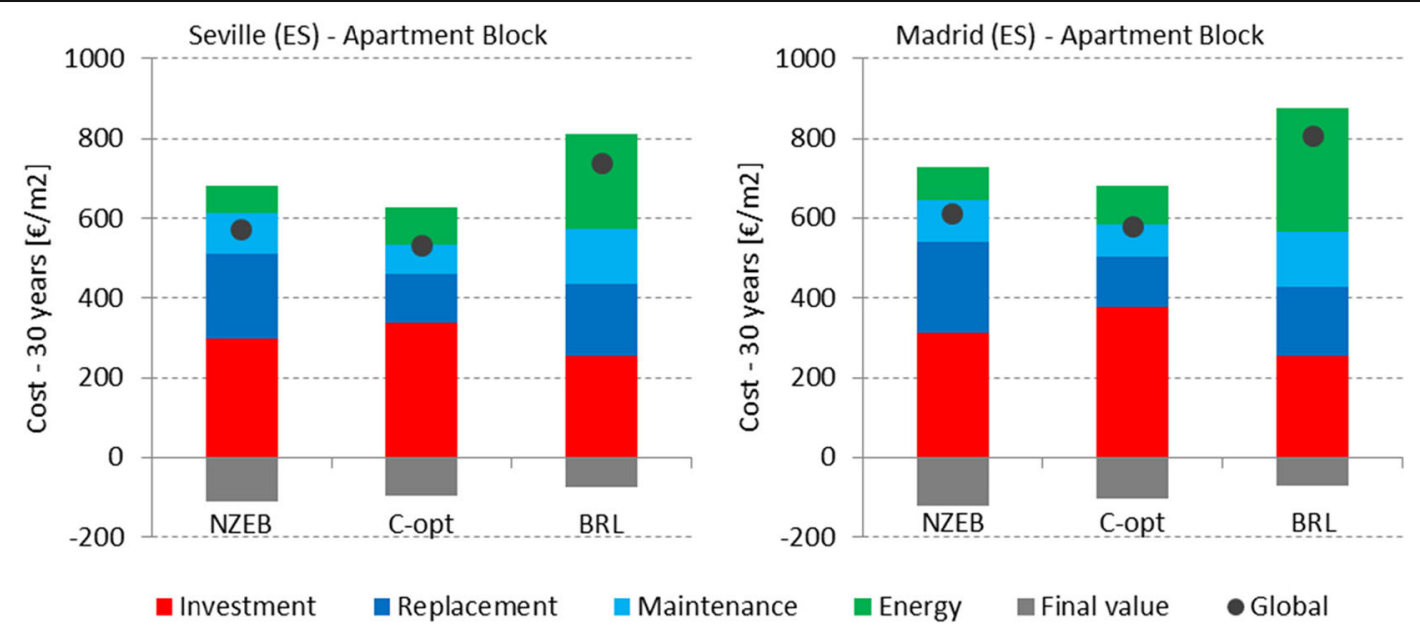

Fig. 7 Breakdown of the costs associated with the retrofit solutions represented by the base refurbishment level and the cost-optimal and NZEB benchmarks for the Spanish apartment blocks

Calculating the global cost

The global costs associated to each building variant were estimated over a period of 30 years, ${ }^{13}$ including the capital costs (initial investment) for renovation, the costs for the substitution of building elements with a lifetime lower than 30 years, the annual maintenance costs, the operating energy costs, the disposal costs, and the final value of considered technologies. Considering a financial perspective, the applicable taxes were considered and all cost items were discounted to 2011 with real interest rates typical of the contests taken into account and based on the EUROSTAT statistics. ${ }^{14}$ The equation of global cost can be written as (Eq. 1):

$C_{\mathrm{G}}(\tau)=\mathrm{CI}+\sum_{f}\left[\sum_{i=1}^{\tau}\left(C_{a, i}(j) \times R_{\mathrm{d}}(i)\right)-V_{f, \tau}(j)\right]$

with $C_{\mathrm{G}}(\tau)$ the global cost referred to the starting year $\tau_{0}$, CI the initial investment costs, $C_{a, i}(j)$ the annual cost for component $j$ at the year $i, R_{\mathrm{d}}$. $i$ ) the discount rate for year $i$, and $V_{f, \tau}(j)$ the final value of component $j$ at the end of the calculation period.

The costs over the calculation period were discounted by means of the discount factor $R_{\mathrm{d}}$, which is calculated as (Eq. 2):

\footnotetext{
${ }^{13}$ It has to be noticed that this calculation period was used for both residential and non-residential building types, in order to obtain comparable results. This choice introduces a difference with respect to the methodology described in the Commission's Guidelines, which sets at 20 years, the calculation period for non-residential buildings.

$14 \mathrm{http}$ ://epp.eurostat.ec.europa.eu/
}

$R_{\mathrm{d}}(p)=\left(\frac{1}{1+r / 100}\right)^{p}$

where $p$ is the number of years of the period and $r$ is the real interest rate.

The cost database, on which the calculation was done, was populated involving national experts who have provided data for the costs of materials, building elements, and related labor. The experts referred mainly to two types of references: existing national (or regional) databases derived from large market-based data gathering and analysis of available data from recent renovation projects and standard commercial offers. In these data collection activity, the main complementary works associated to each refurbishment action were taken into account (e.g., renovation of the doorsteps due to interventions on the floors and suspended ceiling modification associated with the installation of an air distribution system).

References on the cost data collected are provided in Tables 13 and 14 for all technologies already introduced above. About this, it is important to notice that significant deviations among countries were observed for some technologies. This reflects the economic differences of the contexts considered, from which the cost of labor mainly depends, but also the lack of harmonization between the national references used.

Also, in the global cost calculations, several assumptions were needed and, instead of using the estimated long-term energy price developments proposed by the Commission Guidelines (European Parliament 2012a, b), the POLES scenarios were applied also for foreseeing the energy prices over the calculation period. They are shown in Fig. 4. 
Table 17 Envelope transmittances of the benchmarks selected in the cost-optimal and NZEB areas for each building type and climate. For opaque surfaces, $U$ values greater than $0.6 \mathrm{~W} / \mathrm{m}^{2} \mathrm{~K}$ refer to the original (not renovated) elements

\begin{tabular}{|c|c|c|c|c|c|c|c|c|c|}
\hline \multicolumn{2}{|c|}{ Climate and building type } & \multicolumn{8}{|c|}{ Envelope thermal transmittance $\left[\mathrm{W} / \mathrm{m}^{2}{ }^{\circ} \mathrm{K}\right]$} \\
\hline & & \multicolumn{3}{|c|}{ Cost-optimal } & \multicolumn{5}{|l|}{ NZEB } \\
\hline & & Wall & Roof & Basement & Window & Wall & Roof & Basement & Window \\
\hline \multirow[t]{4}{*}{ Seville (ES) } & SFH & 0.31 & 0.33 & 0.31 & 2.60 & 0.31 & 0.33 & 0.31 & 1.71 \\
\hline & $\mathrm{AB}$ & 0.31 & 0.33 & 0.31 & 5.83 & 0.22 & 0.23 & 0.22 & 1.69 \\
\hline & Office & 1.37 & 1.29 & 1.54 & 2.72 & 0.16 & 0.13 & 0.20 & 2.11 \\
\hline & School & 0.46 & 0.53 & 0.55 & 5.85 & 0.28 & 0.21 & 0.31 & 2.10 \\
\hline \multirow[t]{4}{*}{ Madrid (ES) } & SFH & 0.31 & 0.23 & 0.50 & 2.60 & 0.18 & 0.12 & 0.22 & 1.71 \\
\hline & $\mathrm{AB}$ & 0.31 & 0.23 & 0.50 & 2.58 & 0.18 & 0.12 & 0.22 & 1.69 \\
\hline & Office & 1.37 & 1.29 & 1.54 & 2.72 & 0.16 & 0.13 & 0.20 & 2.11 \\
\hline & School & 1.37 & 2.19 & 2.57 & 2.71 & 0.16 & 0.13 & 0.21 & 2.10 \\
\hline \multirow[t]{4}{*}{ Rome (IT) } & SFH & 0.30 & 0.32 & 0.32 & 2.60 & 0.22 & 0.23 & 0.23 & 1.71 \\
\hline & $\mathrm{AB}$ & 0.30 & 0.32 & 0.32 & 1.69 & 0.22 & 0.23 & 0.23 & 1.69 \\
\hline & Office & 0.27 & 0.20 & 0.29 & 2.11 & 0.15 & 0.13 & 0.21 & 2.11 \\
\hline & School & 0.27 & 0.20 & 0.29 & 2.10 & 0.15 & 0.13 & 0.21 & 2.10 \\
\hline \multirow[t]{4}{*}{ Milan (IT) } & SFH & 0.17 & 0.12 & 0.23 & 1.71 & 0.17 & 0.12 & 0.23 & 1.71 \\
\hline & $\mathrm{AB}$ & 0.22 & 0.18 & 0.32 & 1.69 & 0.17 & 0.12 & 0.23 & 1.69 \\
\hline & Office & 0.27 & 0.20 & 0.29 & 0.77 & 0.13 & 0.13 & 0.21 & 0.77 \\
\hline & School & 0.27 & 0.20 & 0.29 & 0.77 & 0.13 & 0.13 & 0.21 & 0.77 \\
\hline \multirow[t]{4}{*}{ Bucharest (RO) } & SFH & 0.22 & 0.18 & 0.30 & 1.03 & 0.18 & 0.12 & 0.22 & 1.03 \\
\hline & $\mathrm{AB}$ & 0.18 & 0.12 & 0.22 & 1.03 & 0.18 & 0.12 & 0.22 & 1.03 \\
\hline & Office & 1.34 & 1.01 & 1.10 & 2.11 & 0.12 & 0.10 & 0.19 & 0.77 \\
\hline & School & 1.34 & 0.70 & 1.10 & 2.10 & 0.12 & 0.10 & 0.19 & 0.77 \\
\hline \multirow[t]{4}{*}{ Vienna (AT) } & SFH & 0.22 & 0.17 & 0.33 & 1.71 & 0.17 & 0.12 & 0.23 & 1.03 \\
\hline & $\mathrm{AB}$ & 0.17 & 0.12 & 0.23 & 1.03 & 0.17 & 0.12 & 0.23 & 1.03 \\
\hline & Office & 0.15 & 0.15 & 0.27 & 0.77 & 0.11 & 0.11 & 0.20 & 0.77 \\
\hline & School & 0.16 & 0.16 & 0.27 & 0.77 & 0.16 & 0.16 & 0.27 & 0.77 \\
\hline \multirow[t]{4}{*}{ Paris (FR) } & SFH & 0.32 & 0.22 & 0.57 & 1.71 & 0.18 & 0.12 & 0.24 & 1.71 \\
\hline & $\mathrm{AB}$ & 0.18 & 0.13 & 0.24 & 1.69 & 0.18 & 0.13 & 0.24 & 1.69 \\
\hline & Office & 1.06 & 1.65 & 3.44 & 2.11 & 0.12 & 0.11 & 0.22 & 0.77 \\
\hline & School & 1.17 & 1.57 & 1.74 & 2.11 & 0.13 & 0.11 & 0.21 & 0.77 \\
\hline \multirow[t]{4}{*}{ Prague (CZ) } & SFH & 0.22 & 0.17 & 0.30 & 1.03 & 0.17 & 0.12 & 0.22 & 1.03 \\
\hline & $\mathrm{AB}$ & 0.63 & 0.65 & 1.24 & 2.66 & 0.17 & 0.11 & 0.22 & 1.03 \\
\hline & Office & 0.15 & 0.09 & 0.22 & 0.78 & 0.15 & 0.09 & 0.22 & 0.78 \\
\hline & School & 0.16 & 0.10 & 0.22 & 0.77 & 0.16 & 0.10 & 0.22 & 0.77 \\
\hline \multirow[t]{4}{*}{ Berlin (DE) } & SFH & 0.21 & 0.17 & 0.29 & 1.03 & 0.16 & 0.12 & 0.21 & 0.70 \\
\hline & $\mathrm{AB}$ & 0.16 & 0.12 & 0.23 & 0.70 & 0.16 & 0.12 & 0.23 & 0.70 \\
\hline & Office & 0.16 & 0.14 & 0.27 & 0.77 & 0.11 & 0.10 & 0.19 & 0.77 \\
\hline & School & 0.16 & 0.15 & 0.27 & 0.77 & 0.11 & 0.10 & 0.19 & 0.77 \\
\hline \multirow[t]{4}{*}{ Helsinki (FI) } & SFH & 0.17 & 0.12 & 0.48 & 1.03 & 0.17 & 0.09 & 0.48 & 0.70 \\
\hline & $\mathrm{AB}$ & 0.17 & 0.10 & 0.48 & 1.03 & 0.17 & 0.10 & 0.48 & 1.03 \\
\hline & Office & 0.09 & 0.09 & 0.16 & 0.78 & 0.13 & 0.12 & 0.21 & 0.78 \\
\hline & School & 0.14 & 0.12 & 0.23 & 0.77 & 0.10 & 0.09 & 0.17 & 0.77 \\
\hline
\end{tabular}


Table 18 Qualitative summary of the thermal systems implemented in the benchmarks selected in the cost-optimal and NZEB areas for each building type and climate

\begin{tabular}{|c|c|c|c|c|c|c|c|c|c|c|c|c|c|}
\hline \multirow{2}{*}{\multicolumn{2}{|c|}{$\begin{array}{l}\text { Climate and } \\
\text { building type }\end{array}$}} & \multicolumn{6}{|c|}{ Cost Optimal } & \multicolumn{6}{|c|}{ NZEB } \\
\hline & & $\begin{array}{l}\text { High-efficiency } \\
\text { H/C generator(s) }\end{array}$ & $\begin{array}{l}\text { Heat } \\
\text { recovery } \\
\text { strategy }\end{array}$ & $\begin{array}{l}\text { High-efficiency } \\
\text { lighting }\end{array}$ & $\begin{array}{l}\text { Thermal } \\
\text { solar } \\
\text { system }\end{array}$ & $\begin{array}{l}\text { Photovoltaic } \\
\text { system }\end{array}$ & $\begin{array}{l}\text { Automatic } \\
\text { natural } \\
\text { ventilation }\end{array}$ & $\begin{array}{l}\text { High-efficiency } \\
\text { H/C generator(s) }\end{array}$ & $\begin{array}{l}\text { Heat } \\
\text { recovery }\end{array}$ & $\begin{array}{l}\text { High-efficiency } \\
\text { lighting }\end{array}$ & $\begin{array}{l}\text { Thermal } \\
\text { solar } \\
\text { system }\end{array}$ & $\begin{array}{l}\text { Photovoltaic } \\
\text { system }\end{array}$ & $\begin{array}{l}\text { Automatic } \\
\text { natural } \\
\text { ventilation }\end{array}$ \\
\hline $\begin{array}{c}\text { Seville } \\
\text { (ES) }\end{array}$ & $\begin{array}{l}\text { SFH } \\
A B \\
\text { Office } \\
\text { School }\end{array}$ & & & & & & & & & & & & 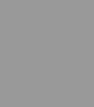 \\
\hline $\begin{array}{l}\text { Madrid } \\
\text { (ES) }\end{array}$ & $\begin{array}{l}\text { SFH } \\
\text { AB } \\
\text { Office } \\
\text { School }\end{array}$ & & & & & & & & & & . & 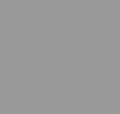 & . \\
\hline $\begin{array}{c}\text { Rome } \\
\text { (IT) }\end{array}$ & $\begin{array}{l}\text { SFH } \\
\text { AB } \\
\text { Office } \\
\text { School }\end{array}$ & & & & & & & & & & & & \\
\hline $\begin{array}{c}\text { Milan } \\
\text { (IT) }\end{array}$ & $\begin{array}{l}\text { SFH } \\
\text { AB } \\
\text { Office } \\
\text { School }\end{array}$ & & & & & & & & & & 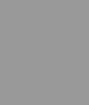 & 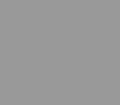 & \\
\hline $\begin{array}{c}\text { Bucharest } \\
\text { (RO) }\end{array}$ & $\begin{array}{ll}\text { SFH } \\
\mathrm{t} & \mathrm{AB} \\
\text { Office } \\
\text { School }\end{array}$ & & & & & & & & & & & & \\
\hline $\begin{array}{l}\text { Vienna } \\
\text { (AT) }\end{array}$ & $\begin{array}{l}\text { SFH } \\
\text { AB } \\
\text { Office } \\
\text { School }\end{array}$ & & & & & & & & & & & & \\
\hline $\begin{array}{l}\text { Paris } \\
\text { (FR) } \\
\end{array}$ & $\begin{array}{l}\text { SFH } \\
\text { AB } \\
\text { Office } \\
\text { School }\end{array}$ & & & & & & & & & & & & \\
\hline $\begin{array}{l}\text { Prague } \\
\text { (CZ) }\end{array}$ & $\begin{array}{l}\text { SFH } \\
A B \\
\text { Office } \\
\text { School }\end{array}$ & & & & & & & & & & & & \\
\hline $\begin{array}{l}\text { Berlin } \\
\text { (DE) }\end{array}$ & $\begin{array}{l}\text { SFH } \\
A B \\
\text { Office } \\
\text { School }\end{array}$ & & & & & & & & & & & & \\
\hline $\begin{array}{l}\text { Helsinki } \\
\text { (FI) }\end{array}$ & $\begin{array}{l}\text { SFH } \\
\text { AB } \\
\text { Office } \\
\text { School }\end{array}$ & & & & & & & & & & & & \\
\hline
\end{tabular}

Where PV systems were installed, two different economic values were associated to the self-consumed and the exported electricity: the market price was used to the self-consumed energy (i.e., an avoided electric consumption); a lower value was considered for the exported electricity instead (i.e., the $35 \%$ of the market price). Taking into account that this differentiation does not have an impact on the energy performance calculations (because a different primary energy factor was not used for the exported electricity), it was assumed that $50 \%$ of electricity yearly generated was self-consumed in the building by the electric loads of thermal systems and lighting. The remaining $50 \%$ was evaluated as exported to the grid. The influence of this simplifying 
assumption on the final results was assessed (see below "Main results" section).

The other main assumptions regarding costs include the choice of the annual maintenance cost and the lifespan of the technologies studied. Both of these data were taken from the standard EN 15459 (CEN 2007d).

Moreover, annual increase rates of costs of the refurbishment actions were taken into account. Specifically, in accordance with Hermelink et al. (2013), an increase rate of $1-2 \%$ per year was applied to the insulation measures; to the low-grade renovation alternatives of window systems; to solar shading devices, lighting systems, and condensing boilers; and to sub-components of distribution, emission, and control. For the high-grade window solutions and to several system options (standard gas boilers, heat pumps and chillers, heat exchangers, and ST and PV panels), a decrease rate of 1-3\% per year was used.

In accordance with the EPBD framework, some economic parameters were considered static over the calculation period. While for the macroeconomic perspective, a real interest rate of $3 \%{ }^{15}$ was used, that one relative to the financial point of view was calculated for each context (Table 15) as difference between the nominal (market) interest rate and the inflation rate. As source, the EUROSTAT data over the period 2008-2011 were used. The tax references needed under financial perspective were collected by the national experts, and the costs of the environmental externalities (carbon price, in $€ / \mathrm{tCO}_{2}$ ) used in the macroeconomic one were obtained with the POLES model as a trend over the period 2011-2050.

To obtain absolute references, the incentive policies in force in the studied national/regional contexts were not taken into account.

Identification of targets and benchmarks

Referring to the scheme shown in Fig. 5, the targets were quantified by post-processing procedures that have automated the analysis of clouds, resulting from the calculation phase. As encouraged ${ }^{16}$ by the EU Regulation (European Parliament 2012a, b), the cost-optimal level was identified

\footnotetext{
${ }^{15}$ This value is suggested as reference by the Commission Guidelines (European Parliament 2012a, b).

16 "In cases where the outcome of the cost-optimal calculations gives the same global costs for different levels of energy performance, Member States are encouraged to use the requirements resulting in lower use of primary energy as the basis for comparison with the existing minimum energy performance requirements" (Annex I, Cap. 6-2).
}

as the minimum (net) primary energy level within the interval (often quite large) with a global cost lower than the absolute minimum one increased by $3 \%$. Otherwise, the NZEB target was obtained incrementing by $10 \mathrm{kWh} /$ $\mathrm{m}^{2} /$ year the minimum primary energy achieved by the best building variant (from the energy point of view). The incremental factors ( $3 \%$ for global cost, $10 \mathrm{kWh} / \mathrm{m}^{2} /$ year for NZEB, as well as those discussed below) are not provided by the Commission Guidelines or by other references. They were defined so as to be suitable for defining targets accessible to different retrofit options.

To provide exemplary technological benchmarks (i.e., packages of exemplary retrofit options satisfying the targets), a portion of the Energy-Cost domain was studied for both targets. These areas are limited inferiorly by the lower frontier of cost-energy cloud (i.e., the profile of cost-optimality), and they were defined applying a range of $\pm 5 \mathrm{kWh} / \mathrm{m}^{2} /$ year in net primary energy and an upper limit of cost equal to the minimum global cost for the specific target increased by $10 \%$. These factors were chosen for identifying areas populated by a number of building variants neither too small nor too big (i.e., about 20-50).

To apply the EPBD principle of priority of efficiency solutions involving the building envelope,${ }^{17}$ the building variants within these areas were further filtered. Firstly, only the cases with energy needs for heating and cooling lower than the minimum value incremented by $10 \mathrm{kWh} / \mathrm{m}^{2} /$ year were considered. Then, the resulting variants were statically analyzed to recognize the more frequently occurring technologies. If the result obtained was not representative of any real variant present in the studied area, priority was given firstly to the most recurrent envelope combination and then to those relative to thermal systems and RES technologies.

\section{Results and discussion}

\section{Main results}

The main aim of this study is to find possible targets of (net) primary energy representative of the cost-optimal and nearly zero-energy levels and to provide examples

\footnotetext{
17 "Member States shall take the necessary measures to ensure that minimum energy performance requirements are set for building elements that form part of the building envelope and that have a significant impact on the energy performance of the building envelope when they are replaced or retrofitted, with a view to achieving cost-optimal levels" (Article 4).
} 


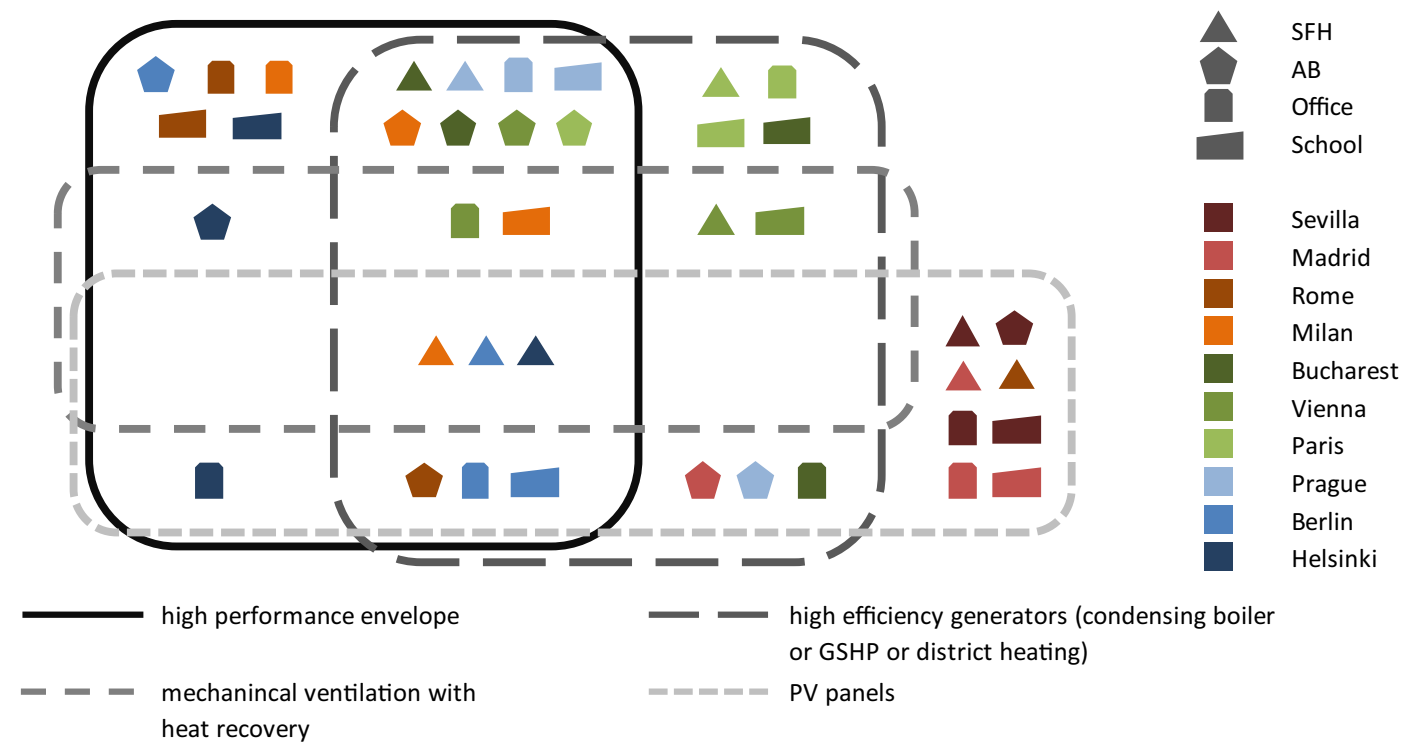

Fig. 8 Schematic representation of the technological benchmarks obtained within the analyzed cost-optimal areas for all building types in all climatic contexts. The 40 cost-optimal buildings are collected in the appropriate set, depending on their classification regarding the performance of the envelope, the efficiency of generators, the presence of a heat recovery strategy, and the presence of a PV system

to the base refurbishment levels. Maximum values of net primary energy for the NZEB targets ${ }^{18}$ of 40,75 , and $100 \mathrm{kWh} / \mathrm{m}^{2}$ were recognized as obtainable respectively for the South, Central, and North European areas. Often (27 times out of 40), the NZEB levels result economically more advantageous (lower global costs) than the base renovation Levels, especially in the Central-North Europe.

About the investment costs - the main barrier to the widespread diffusion of efficient refurbishments - it has to be noticed that their average increases with respect to the BRL for the cost-optimal and NZEB targets are respectively of 50 and $115 \%$. However, some results demonstrate the possibility to reduce the base refurbishment investment costs, moving towards cost-optimal solutions. For instance, this is the case of the residential types located in Milan and Vienna, where the improvement of the building envelopes allows avoid the expenditure related to the installation or substitution of an active cooling system.

Interesting are also the cases of the apartment blocks located in Spain (Seville and Madrid), where the NZEB benchmarks have a lower investment cost of the cost-optimal ones. However, in spite of the fact they also have lower energy running costs, the global

\footnotetext{
${ }^{18}$ These maximum values are always associated to the apartment block type that shows a lower energy saving potential due to geometric limits (e.g., lower available roof surface for solar systems).
} 
Table 19 Influence of the boundary conditions on the cost-optimal targets, in terms of percentage difference in (net) primary energy with respect to the reference condition (financial perspective with starting year 2011 and "Reference" scenario)

\begin{tabular}{|c|c|c|c|c|}
\hline \multicolumn{2}{|c|}{ Climate and building type } & \multirow{2}{*}{$\begin{array}{l}\text { Financial perspective } \\
\text { "Ambitious" (\%) }\end{array}$} & \multicolumn{2}{|c|}{ Macroeconomic perspective } \\
\hline & & & "Reference" (\%) & "Ambitious" (\%) \\
\hline \multirow[t]{4}{*}{ Seville (ES) } & SFH & -13 & 19 & -13 \\
\hline & $\mathrm{AB}$ & -8 & 7 & -8 \\
\hline & Office & $=$ & $=$ & -10 \\
\hline & School & -22 & $=$ & -20 \\
\hline \multirow[t]{4}{*}{ Madrid (ES) } & SFH & -19 & 10 & -37 \\
\hline & $\mathrm{AB}$ & -12 & $=$ & -16 \\
\hline & Office & $=$ & $=$ & 29 \\
\hline & School & $=$ & $=$ & -36 \\
\hline \multirow[t]{4}{*}{ Rome (IT) } & SFH & -20 & 7 & -35 \\
\hline & $\mathrm{AB}$ & -13 & $=$ & -30 \\
\hline & Office & -68 & 10 & -74 \\
\hline & School & -19 & $=$ & -43 \\
\hline \multirow[t]{4}{*}{ Milan (IT) } & SFH & -13 & $=$ & -21 \\
\hline & $\mathrm{AB}$ & -17 & -8 & -17 \\
\hline & Office & -70 & -15 & -88 \\
\hline & School & -25 & $=$ & -33 \\
\hline \multirow[t]{4}{*}{ Bucharest (RO) } & SFH & -36 & $=$ & -49 \\
\hline & $\mathrm{AB}$ & -7 & $=$ & $=$ \\
\hline & Office & -72 & $=$ & -63 \\
\hline & School & -50 & $=$ & -30 \\
\hline \multirow[t]{4}{*}{ Vienna (AT) } & SFH & -9 & -9 & -17 \\
\hline & $\mathrm{AB}$ & -10 & $=$ & -14 \\
\hline & Office & -26 & -6 & -22 \\
\hline & School & -25 & $=$ & -14 \\
\hline \multirow[t]{4}{*}{ Paris (FR) } & SFH & -25 & -10 & -16 \\
\hline & $\mathrm{AB}$ & -24 & $=$ & -15 \\
\hline & Office & -73 & $=$ & -16 \\
\hline & School & -58 & -33 & -36 \\
\hline \multirow[t]{4}{*}{ Prague (CZ) } & SFH & -14 & $=$ & -45 \\
\hline & $\mathrm{AB}$ & $=$ & $=$ & $=$ \\
\hline & Office & -19 & $=$ & -36 \\
\hline & School & $=$ & $=$ & -43 \\
\hline \multirow[t]{4}{*}{ Berlin (DE) } & SFH & -12 & $=$ & $=$ \\
\hline & $\mathrm{AB}$ & -7 & $=$ & -7 \\
\hline & Office & -22 & $=$ & -18 \\
\hline & School & -11 & 79 & 19 \\
\hline \multirow[t]{4}{*}{ Helsinki (FI) } & SFH & -14 & -9 & -14 \\
\hline & $\mathrm{AB}$ & $=$ & $=$ & $=$ \\
\hline & Office & $=$ & -13 & $=$ \\
\hline & School & -8 & -40 & -26 \\
\hline
\end{tabular}

"=" no relevant variation (range between $\pm 5 \%$ ) 


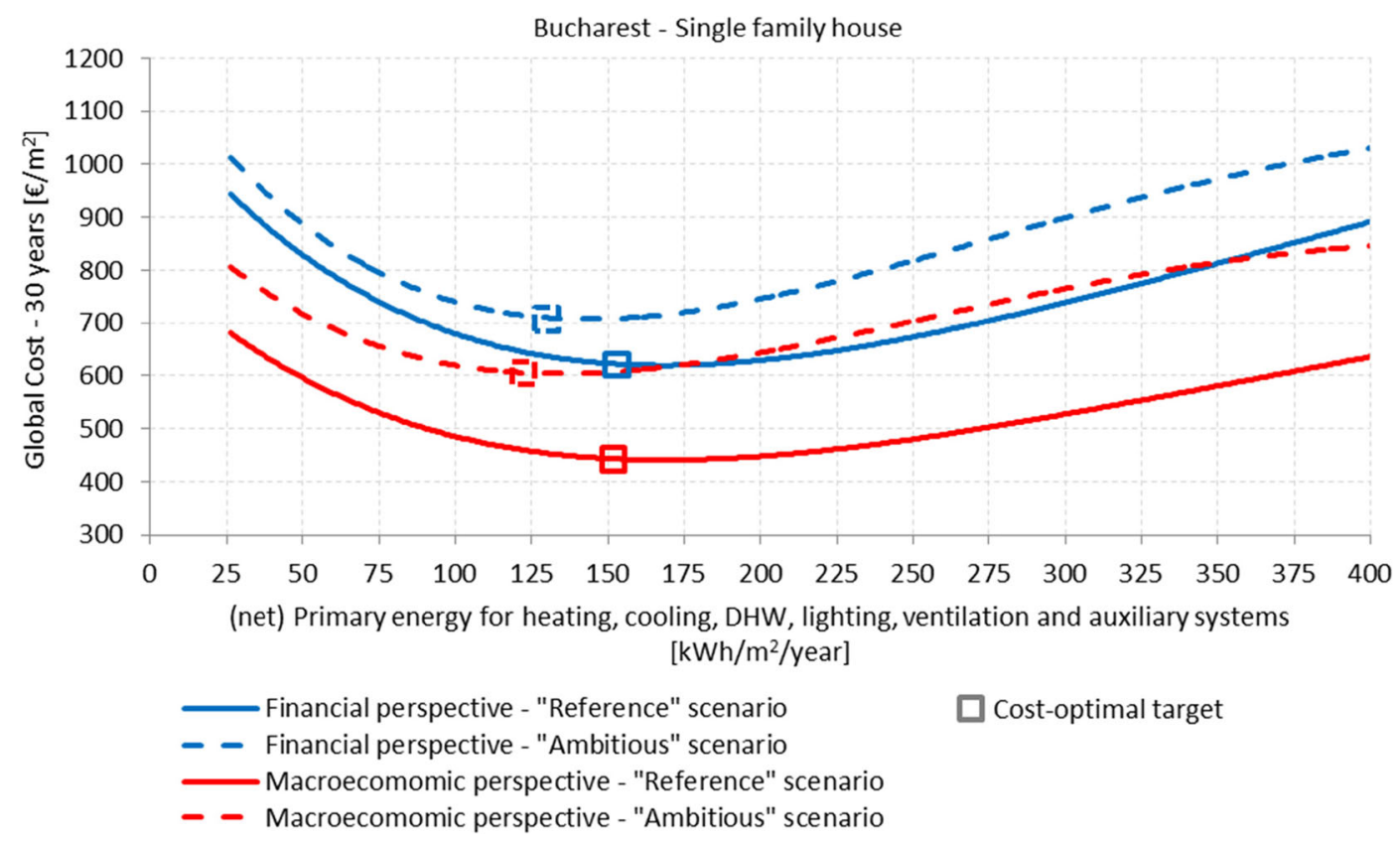

Fig. 9 Example of change in the lower profile of the Energy-Cost cloud depending on economical perspective and price scenario

costs are slightly higher than the cost-optimal retrofit solution. This can be explained by analyzing the other cost items considered in the calculation. As shown in Fig. 7, the NZEB benchmarks have higher replacement and maintenance costs, also because of retrofit solutions with lower lifespan (e.g., fancoils) compared to more expensive alternatives (e.g., radiant floor). This type of result is due to the contingent proximity between the cost-optimal and NZEB areas for these Spanish cases, but it is also symptomatic of the methodology applied (i.e., non based on multistage optimization techniques).

In general, the NZEB area appears characterized by medium-high and high recurrences of efficiency and RES technologies in all countries and for both the building destinations. For instance, a typical NZEB building has a well-insulated envelope (including insulation layers of $10-30 \mathrm{~cm}$ and double or triple low-e windows), efficient generators (e.g., condensing boiler or ground source heat pump or district heating) in some case assisted by heat recovery strategies, and renewable solar systems installed (normally both thermal and photovoltaic). More details are provided below in Tables 17 and 18 for each building and climatic condition.

Otherwise, the cost-optimal benchmarks are more heterogonous. Various are the retrofit solutions able to reach this target, that overall is characterized by the competition between the deepest actions regarding envelope, thermal systems, and solar renewable systems. Figure 8 provides a qualitative overview of costoptimal benchmarks which are classified in function of their strengths. As expected, it is difficult to minimize the global costs applying a high-performance envelope, very efficient generators, a heat recovery strategy, and a PV plant at the same time. This occurs only for the single-family houses located in Milan, Berlin, and Helsinki, which lie in the intersection of all sets.

Filtering also on the energy needs for heating and cooling (as discussed above), more than half (23 cases) of the benchmarks obtained are characterized by

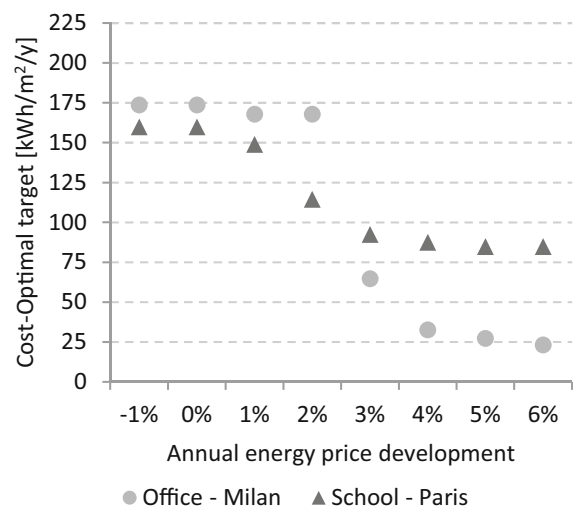

Fig. 10 Dependency of the resulting cost-optimal target from the energy prices development for two case studies (office in Milan and school in Paris) 
Fig. 11 Dependency of the resulting cost-optimal target from the real interest rate (a) and the calculation period (b) (office in Milan)

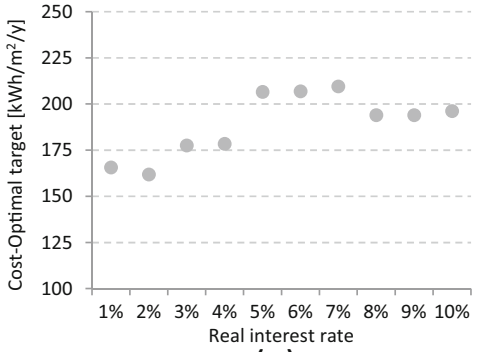

(a)

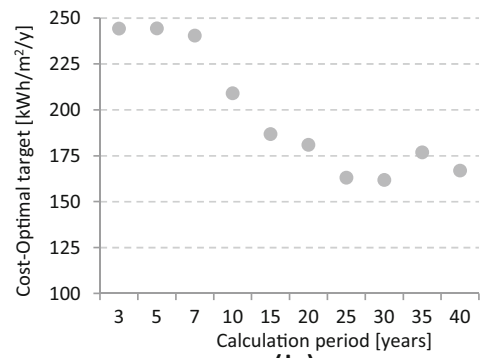

(b) medium-high levels of insulation $(10-20 \mathrm{~cm})$ and by double or triple glazing low-e windows. In 16 cases, the deep grade renovation of envelope is coupled with the installation of an efficient generators (condensing boiler or ground source heat pump or connection to district heating). Only for four residential building variants, there is also the presence of heat recovery strategies and photovoltaic generation. Among these, it is interesting the case of the single house in Milan, where the costoptimal variant results those with the best envelope solutions ${ }^{19}$ because it avoids the need for active cooling systems. Differently, for other South European types (particularly in the Spanish contexts, where the saving potential of envelope strategies is lower and the solar radiation is higher), the cost-optimal level can be represented by medium-low envelope renovations compensated by photovoltaic systems.

About the thermal systems, normally, both costoptimal and NZEB targets require the substitution of the original thermal generators with more efficient technologies and the insulation of distribution pipes. Particularly, in the cost-optimal area, the penetration of simple system layouts is favored (e.g., reversible heat pump coupled to a single distribution and emission system). Otherwise, the mechanical ventilation strategies (often associated to heat recovery) can get into economic competition with envelope and RES solutions, also in the NZEB area. ${ }^{20}$ Medium-low

\footnotetext{
${ }^{19}$ With automatized night natural ventilation and high-performance solar shading systems, as well as high insulation levels and very low infiltrations during the day.

${ }^{20}$ In this study, the penetration of mechanical ventilation with or without heat recovery, is compared with a good user behavior of occupants, who correctly open windows when air changes are needed, avoiding excessive openings. This helps to obtain natural ventilation solutions in the cost-optimal and sometimes also in the minimum net primary energy area more often with respect to mechanical ventilation. Clear real time signals on IAQ and training of occupants, in this way, could be a cost-effective strategy to reduce the initial investment, annual, and energy costs, without reducing the indoor air quality.
}

temperature emission systems for heating often occur both in the NZEB and cost-optimal areas. In some climate contexts, biomass and district heating systems occur with low frequency in the benchmark areas. This might be due also to difficulties in defining the actual primary energy factors, the investment costs (due to different installation conditions), and the energy prices (due to private negotiation).

RES technologies represent a key strategy to reach the zero-energy target in all the analyzed contexts (e.g., also for the residential buildings of Berlin). Moreover, the more efficient lighting strategies appear always a good intervention to reach NZEB area, especially in office buildings.

Being a crucial aspect of the EPBD framework, in order to provide more detailed information about the features of the selected retrofit solutions, the thermal transmittances obtained for the main envelope elements are presented in Table 17 and qualitative indications of thermal systems adopted are shown in Table 18, for both the cost-optimal and NZEB areas.

\section{Sensitivity analysis}

In compliance with the EU cost-optimal Regulation ${ }^{21}$ (European Parliament 2012a, b), it is interesting to study the influence of some key input data on the main calculation results. As discussed above, in the present study, the macroeconomic perspective was also evaluated and two energy price scenarios ("Ambitious" besides "Reference") were considered.

\footnotetext{
21 "Member States shall undertake an analysis to determine the sensitivity of the calculation outcomes to changes in the applied parameters, covering at least the impact of different energy price developments and the discount rates for the macroeconomic and financial calculations, ideally also other parameters which are expected to have a significant impact on the outcome of the calculations such as price developments for other than energy" (Article 3).
} 


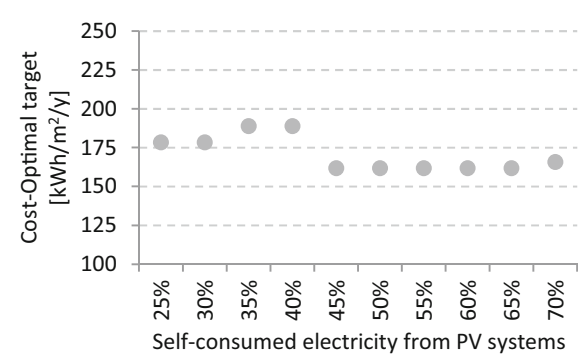

Fig. 12 Dependency of the resulting cost-optimal target from the percentage of self-consumed electricity from PV systems (office in Milan)

In order to provide a quantitative overview of the influence of these standpoints on the lower frontier (i.e., the optimal frontier) of the Energy-Cost clouds, the changes of the cost-optimal targets are reported in Table 19. In general, the higher energy price scenario ("Ambitious") increases the global costs (mainly composed of initial investment and running costs due to energy) of the less efficient variants and leads to a lower value of net primary energy for the cost-optimal level. Not considering taxes and introducing the prices for $\mathrm{CO}_{2}$ emissions, as required by the macroeconomic perspective, the global costs of the more efficient refurbishments decrease, moving again the cost-optimal target towards the NZEB one. These effects are shown for an exemplary case in Fig. 9.

The higher energy price scenarios increase the minimum global cost range and lead to a lower value of net primary energy for cost-optimal levels, as well as the increase of prices for $\mathrm{CO}_{2}$ emissions (and eventual costs related to environmental damages or other externalities). In some cases, the cost-optimal profiles are very flat and this can imply that a moderate change of input data results in a significant variation of outputs.

As discussed by Boermans et al. (2011), the assumed development of energy prices is one of the most critical input data because many energy prices have a strong national (or regional or even local) influence and the forecasts have to take into account expected longer-term political and economic developments. Moreover, its overall influence on the final results is not necessarily linear, and indeed discontinuities can be observed. For instance, referring again to the identification of the costoptimal target, this is the case of our school located in Paris and mostly the office in Milan (Fig. 10). Here, varying all energy prices (i.e., electricity and natural gas) by the same annual developments in the range $-1 / 6 \%$, the optimum selection procedure reveals a pronounced discontinuity between 2 and $3 \%$. This effect is more relevant for those building types characterized by a costoptimal frontier very flat.

Other calculation parameters for which a sensitivity analysis is recommended by the EC Regulation are the real interest rate and the calculation period. For these variables, a more linear dependency was observed, as shown in Fig. 11 for the example of the office located in Milan. As expected, the cost-optimal target increases with increasing real interest rate because the future economic savings (greater for low net primary energy levels) are more discounted at high interest rates. Otherwise, the target decrease with increasing the calculation period until the thirtieth year and slightly increase after, because of the periodic costs for replacement occurring at year $31,{ }^{22}$ which are greater for the more efficient renovation packages.

Because of the assumption made on the selfconsumption of the electricity generated on-site by the photovoltaic systems (set to $50 \%$ for all building types), it is interesting to evaluate the influence of this variable of the final results. As shown below for the critical case of the Milanese office (Fig. 12), a minor influence was observed, especially in the range $45-70 \%$.

\section{Conclusions}

The first cost-optimal calculations of the European Member States ${ }^{23}$ have been recently evaluated by the European Commission (Boermans et al. 2015; Zirngibl and Bendzalova 2015), and it is quite evident that different interpretations of the procedure prescribed by the EPBD framework were adopted. The present large-scale study provides reliable references obtained under common boundary conditions and calculation assumptions for a representative sample of the EU-28 area. The quantitative results found here for the refurbishment sector are obviously depending on the typologies of selected buildings, but they allow a direct comparison between a high number of climatic and economic contexts across the EU.

Taking as reference the existing buildings of $60 \mathrm{~s}-$ $70 \mathrm{~s}$, the energy saving potential of found cost-optimal

\footnotetext{
22 According to Standard EN 15459 (CEN 2007d), a lifetime of 30 years was considered to the majority of envelope technologies.

23 The MS's reports are available on http://ec.europa. eu/energy/en/topics/energy-efficiency/buildings
} 
targets are very relevant (36-88\% in term of net primary energy) for all analyzed cases and the achieved NZEB levels resulted interesting also from an economic point of view: their global costs (over 30 years) are often lower than the respective base refurbishment levels (as defined in this study) and never greater than $33 \%$.

While a further recast of EPBD has been announced and it is under approval, it is interesting to observe that the EPBD framework provides a useful guidance for cost-optimal calculations. However, to achieve a more uniform implementation in the Member States (or at least to improve the comparison possibilities), more detailed indications would be needed and some boundary conditions should be better defined. Taking into account the methodology developed within this study and the application to a quite large amount of building types and climatic/ economic conditions, some suggestions can be provided.

The method used to calculate the energy demands associated to the building renovations provides a good compromise between detail and simulation effort, for this type of study. The preliminary choice to develop the analysis avoiding search-optimization techniques makes an easier comparison between retrofit options (sometimes competing among themselves) and allows an easier assessment of the influence of the main calculation parameters. However, the high number of building variants can complicate the analysis and interpretation of final results, which depend on many calculation factors.

The comparison of the retrofit variants in the primary energy/global costs domain allows identifying quite clearly some reference targets and technical solutions that can guide the development of new energy requirements and targeted policy. However, the clouds (or curves) obtained cannot show explicit information about the energy needs for the different energy end-uses of a building and the initial investment costs of a renovation action. Details about these aspects should be explicitly requested by the procedure and references about the priority of technologies taken into account for the selection of benchmark should be clarified.

While, for new buildings, it is quite simple to define a reference building variant (e.g., the one that meets the current energy requirements), this aspect is not fully regulated for existing buildings. For the calculation experience here reported, the concept of base refurbishment level was introduced to obtain homogeneous building variants (in terms of functionality, esthetic aspect, and comfort levels) and to recognize which costs could be omitted. This baseline has proved a useful reference for a direct evaluation of the results, and it should be proposed for further applications of the EPBD calculation framework.

As a function of the cost range chosen, the costoptimal area can be very wide in terms of net primary energy range and the simple encouragement for the minimum target of (net) primary energy could represent a too soft indication that could introduce discrepancies between the analyses of the different Member States. The choice of the cost range should be standardized: in this study, an increment of $3 \%$ was applied on the minimum value of global cost.

The collection of consistent and reliable data for costs associated to the renovation actions is undoubtedly one of the most critical steps of this kind of analysis. Because erroneous data or non-homogeneous database may have a substantial influence on the final results, solid references should be defined and provided to Member States by the European Commission. As starting point, the national databases used for the first run of cost-optimal calculations done by the Member States, as well as those developed within parallel studies (as the one discussed here), should be considered.

The EU cost-optimal methodology focuses on the building variants of the lower frontier of the EnergyCost clouds. Of course, this part of the graphs represents the most profitable solutions in terms of global costs, but also the variants with higher global costs might represent interesting solutions in terms of environmental value or energy efficiency solutions that might reach the cost-optimal area if supported with incentive policies. To evaluate this possibility, it is essential to define as much as possible the EnergyCost clouds, rather than limiting the analysis to optimization procedures able to produce only the costoptimal curve.

Acknowledgements We are grateful to all Partners of the ENTRANZE project for their contributions and in particular to the project coordinator Lukas Kranzl (Energy Economics Group, Vienna University of Technology) and to Maria Fernandez Boneta and Ines Diaz Regodon (CENER) for great scientific and technical support. 


\section{Compliance with ethical standards}

Conflict of interest The authors declare that they have no conflict of interest.

Open Access This article is distributed under the terms of the Creative Commons Attribution 4.0 International License (http:// creativecommons.org/licenses/by/4.0/), which permits unrestricted use, distribution, and reproduction in any medium, provided you give appropriate credit to the original author(s) and the source, provide a link to the Creative Commons license, and indicate if changes were made.

\section{References}

Artmann, N., Manz, H., \& Heiselberg, P. (2007). Climatic potential for passive cooling of buildings by night-time ventilation in Europe. Applied Energy, 84, 187-201.

Asadi, E., da Silva, M. G., Antunes, C. H., \& Dias, L. (2012). A multi-objective optimization model for building retrofit strategies using TRNSYS simulations, GenOpt and MATLAB. Building and Environment, 56, 370-378.

Ashrafiana, T., Yilmaz, A. Z., Corgnati, S. P., \& Nazanin Moazzen, N. (2016). Methodology to define cost-optimal level of architectural measures for energy efficient retrofits of existing detached residential buildings in Turkey. Energy and Buildings, 120(2016), 58-77.

Attia, S., Hamdy, M., O’Brien, W., \& Carlucci, S. (2013). Assessing gaps and needs for integrating building performance optimization tools in net zero energy buildings design. Energy and Buildings, 60, 110-124.

Ballarini, I., Corgnati, S. P., \& Corrado, V. (2014). Use of reference buildings to assess the energy saving potentials of the residential building stock: the experience of TABULA project. Energy Policy, 68, 273-284.

Becchio, C., Corgnati, S. P., Orlietti, L., \& Spigliantini, G. (2015). Proposal for a modified cost-optimal approach by introducing benefits evaluation. Energy Procedia, 82, 445-451.

Becchio, C., Ferrando, D. G., Fregonara, E., Milani, N., Quercia, C., \& Serra, V. (2016). The cost-optimal methodology for the energy retrofit of an ex-industrial building located in Northern Italy. Energy and Buildings, 127, 590-602.

Boermans, T., Bettgenhäuser, K., Hermelink, A., \& Schimschar, S. (2011). Cost optimal building performance requirements. Calculation methodology for reportingon national energy performance requirements on the basis of cost optimality within the framework of the EPBD. European Council for an Energy Efficient Economy (ECEEE).

Boermans, T., Grözinger, J., von Manteuffel, B., Surmeli-Anac, N., John, A., Klemens Leutgöb, K., Bachner, D. (2015). Assessment of cost optimal calculations in the context of the EPBD. Final report of Project number: BUIDE13705, Ecofys 2015 by order of European Commission.
Brandão de Vasconcelos, A., Duarte Pinheiro, M., Manso, A., \& Cabaço, A. (2016). EPBD cost-optimal methodology: application to the thermal rehabilitation of the building envelope of a Portuguese residential reference building. Energy and Buildings, 111, 12-25.

Brown, C., Glicksman, L., \& Lehar, M. (2010). Toward zero energy buildings: optimized for energy use and cost. 2010, Fourth National Conference of IBPSA-USA, pp 452-457.

Carlucci, S. (2013). Comfortable net zero energy buildings - a building optimization process based on the minimization of thermal discomfort. Milan: SpringerBriefs in Applied Sciences and Technology, Springer.

CEN (2000). EN 12207:2000. Windows and doors - Air permeability - Classification.

CEN (2005). EN 15316-3-1:2005. Heating systems in buildings Method for calculation of system energy requirements and system efficiencies-Part 3-1: Domestic hot water systems, characterisation of needs.

CEN (2007a). EN 15243:2007. Ventilation for buildings. Calculation of room temperatures and of load and energy for buildings with room conditioning systems.

CEN (2007b). EN 15251:2007. Indoor environmental input parameters for design and assessment of energy performance of buildings addressing indoor air quality, thermal environment, lighting and acoustics.

CEN (2007c). EN 15316:2007. Heating systems in buildings. Method for calculation of system energy requirements and system efficiencies.

CEN (2007d). EN 15459:2007. Energy performance of buildingseconomic evaluation procedure for energy systems in buildings.

CEN (2008). EN 15603:2008. Energy performance of buildings. Overall energy use and definition of energy ratings.

CEN (2012). EN 14825:2012. Air conditioners, liquid chilling packages and heat pumps, with electrically driven compressors, for space heating and cooling. Testing and rating at part load conditions and calculation of seasonal performance.

Commission Decision 2013/114/EU of 1 March 2013 (2013). Establishing the guidelines for Member States on calculating renewable energy from heat pumps from different heat pump technologies pursuant to Article 5 of Directive 2009/28/EC of the European Parliament and of the Council", Official Journal of the European Union (L 62/27).

Corgnati, S. P., Fabrizio, E., Filippi, M., \& Monetti, V. (2013). Reference buildings for cost optimal analysis: method of definition and application. Applied Energy, 102, 983-993.

Corrado, V., Ballarini, I., \& Paduos, S. (2014). Assessment of costoptimal energy performance requirements for the Italian residential building stock. Energy Procedia, 45, 443-452.

Deuble, M. P., \& de Dear, R. J. (2012). Mixed-mode buildings: a double standard in occupants' comfort expectations. Building and Environment, 54, 53-60.

Diakaki, C., Grigoroudis, E., \& Kolokotsa, D. (2008). Towards a multi-objective optimization approach for improving energy efficiency in buildings. Energy and Buildings, 40, 17471754.

European Commission (2006). Energy Technologies, Knowledge, Perception, Measures (Eurobarometer). 
European Commission, EU Energy (2014). Transport and GHG Emissions. Trends to 2050, Reference Scenario 2013.

European Parliament (2010). EPBD recast, Directive 2010/31/EU of the and of Council of 19 May 2010 on the energy performance of buildings (recast). Official Journal of the European Union.

European Parliament (2012a). Commission Delegated Regulation (EU) No 244/2012 of 16 January 2012 supplementing Directive 2010/31/EU of the European Parliament and of the Council on the energy performance of buildings by establishing a comparative methodology framework for calculating cost-optimal levels of minimum energy performance requirements for buildings and building elements. Official Journal of the European Union.

European Parliament (2012b). Guidelines accompanying Commission Delegated Regulation (EU) No. 244/2012 of 16 January 2012 supplementing Directive 2010/31/EU of the European Parliament and of the Council on the energy performance of buildings by establishing a comparative methodology framework for calculating cost-optimal levels of minimum energy performance requirements for buildings and building elements.

Evins, R. (2013). A review of computational optimisation methods applied to sustainable building design. Renewable and Sustainable Energy Reviews, 22, 230-245.

Ferrara, M., Fabrizio, E., Virgone, J., \& Filippi, M. (2014). A simulation-based optimization method for cost-optimal analysis of nearly Zero Energy Buildings. Energy and Buildings, $84,442-457$.

Fesanghary, M., Asadi, S., \& Geem, Z. W. (2012). Design of lowemission and energy-efficient residential buildings using a multi-objective optimization algorithm. Building and Environment, 49, 245-250.

Fokaides, P. A., \& Papadopoulos, A. M. (2014). Cost-optimal insulation thickness in dry and mesothermal climates: existing models and their improvement. Energy and Buildings, 68, 203-212.

Ganic, N., \& Zerrin Yilmaz, A. (2014). Adaptation of the cost optimal level calculation method of Directive 2010/31/EU considering the influence of Turkish national factors. Applied Energy, 123, 94-107.

Hamdy, M., Hasan, A., \& Siren, K. (2013). A multi-stage optimization method for cost-optimal and nearly-zero-energy building solutions in line with the EPBD-recast 2010. Energy and Buildings, 56, 189-203.

Hermelink, A., Schimschar, S., Boermans, T., Pagliano, L., Zangheri, P., Armani, R., Voss, K., \& Musall, E. (2013). Towards nearly zero-energy buildings - definition of common principles under the EPBD - final report”. Ecofys 2012 by order of: European Commission.

IPCC (2007). Core Writing Team, Pachauri, R.K and Reisinger, A. Climate Change 2007: Synthesis Report. Contribution of Working Groups I, II and III to the Fourth Assessment Report of the Intergovernmental Panel on Climate Change. IPCC, Geneva, Switzerland.

ISO (2007). ISO 6946:2007. Building components and building elements. Thermal resistance and thermal transmittance. Calculation method.
Kumbaroğlu, G., \& Madlener, R. (2012). Evaluation of economically optimal retrofit investment options for energy savings in buildings. Energy and Buildings, 49, 327-334.

Kurnitski, J., Saarib, A., Kalameesc, T., Vuolled, M., Niemeläd, J., \& Tarke, T. (2011). Cost optimal and nearly zero (nZEB) energy performance calculations for residential buildings with REHVA definition for nZEB national implementation. Energy and Buildings, 43, 3279-3288.

Lapillonne, B., Sebi, C., Pollier, K., \& Mairet, N. (2012). Energy Efficiency Trends in Buildings in the EU-Lessons from the ODYSSEE MURE project.

Lu, Y., Wang, S., \& Shan, K. (2015). Design optimization and optimal control of grid-connected and standalone nearly/net zero energy buildings. Applied Energy, 155, 463-477.

Machairas, V., Tsangrassoulis, A., \& Axarli, K. (2014). Algorithms for optimization of building design: a review. Renewable and Sustainable Energy Reviews, 31, 101-112.

Marszal, A., Heiselberg, P., Bourrellé, J., Musall, E., Voss, K., Sartori, I., \& Napolitano, A. (2011). Zero Energy Buildinga review of definitions and calculation methodologies. Energy and Buildings, 43, 971-979.

Morrissey, J., \& Horne, R. E. (2011). Life cycle cost implications of energy efficiency measures in new residential buildings. Energy and Buildings, 43, 915-924.

Nguyen, A. T., \& Reiter, S. (2014). Passive designs and strategies for low-cost housing using simulation-based optimization and different thermal comfort criteria. Journal of Building Performance Simulation, 7, 68-81.

Nguyen, A., Reiter, S., \& Rigo, P. (2014). A review on simulationbased optimization methods applied to building performance analysis. Applied Energy, 113, 1043-1058.

Nicol, F., \& Humphreys, M. (2010). Derivation of the adaptive equations for thermal comfort in free-running buildings in European standard EN15251. Building and Environment, 45(1), 11-17.

Ortiz, J., Fonseca i Casas, A., Salom, J., Garrido Soriano, N., \& Fonseca i Casas, P. (2016a). Comfort and economic criteria for selecting the optimal passive measures for the energy renovation of residential buildings in Catalonia. Energy and Buildings, 110, 195-210. https://doi.org/10.1016/j. enbuild.2015.10.022.

Ortiz, J., Fonseca i Casas, A., Salom, J., Garrido Soriano, N., \& Fonseca i Casas, P. (2016b). Cost-effective analysis for selecting energy efficiency measures for refurbishment of residential buildings in Catalonia. Energy and Buildings, 128(2016), 442-457.

Pagliano, L., \& Zangheri, P. (2010). Comfort models and cooling of buildings in the Mediterranean zone. Advances in Building Energy Research, 4(b), 167-200.

Pascual Buisán, M. A., Díaz Regodón, I., Zubiri Azqueta, E., Tirapu Francés, F. J. (2012). Guía IDAE: Manual de fundamentos técnicos de calificación energética de edificios existentes CE3X. Depósito Legal: M-26890-2012, Madrid, Julio 2012.

Penna, P., Prada, A., Cappelletti, F., \& Gasparella, A. (2015). Multi-objectives optimization of energy efficiency measures in existing buildings. Energy and Buildings, 95, 57-69. 
Pikas, E., Thalfeldt, M., \& Kurnitski, J. (2014). Cost optimal and nearly zero energy building solutions for office buildings. Energy and Buildings, 74, 30-42.

Rysanek, A. M., \& Choudhary, R. (2013). Optimum building energy retrofits under technical and economic uncertainty. Energy and Buildings, 57, 324-337.

Sanchez de la Flora, F. J., Salmeron Lissen, J. M., \& Alvarez Dominguez, S. (2006). A new methodology towards determining building performance under modified outdoor conditions. Building and Environment, 41, 1231-1238.

Solar Energy Laboratory (2012). TRNSYS 17.1. University of Wisconsin.

Tadeu, S. F., Alexandre, R. F., Tadeu, A. J. B., Antunes, C. H., Simões, N. A. V., \& da Silva, P. P. (2016). A comparison between cost optimality and return on investment forenergy retrofit in buildings - a real options perspective. Sustainable Cities and Society, 21(2016), 12-25.

UNI (2008). UNI/TS 11300-2:2008. Energy performance of buildings. Part 2: evaluation of primary energy need and of system efficiencies for space heating and domestic hot water production.

United States Department of Energy (2013). EnergyPlus Verison 7.2 Documentation, Engineering Reference.

Wetter, M. (2008). GenOpt - Generic Optimization Program. User Manual Version 2.1.0. Lawrence Berkeley National Laboratory.

Zirngibl, J., Bendzalova J. (2015). Technical assessment of national/regional calculation methodologies for the energy performance of buildings. Final report of contract $n^{\circ}$ ENER/c3/2013-425/sI2.679523. 